\title{
BM] Global Health Estimating need and coverage for five priority assistive products: a systematic review of global population- based research
}

\author{
Jamie Danemayer (D) , ${ }^{1}$ Dorothy Boggs (D) , ${ }^{2}$ Vinicius Delgado Ramos, ${ }^{3}$ \\ Emma Smith, ${ }^{4}$ Ariana Kular, ${ }^{5}$ William Bhot, ${ }^{1}$ Felipe Ramos-Barajas (1) , ${ }^{1}$ \\ Sarah Polack, ${ }^{2}$ Cathy Holloway ${ }^{1}$
}

To cite: Danemayer J, Boggs D, Delgado Ramos V, et al. Estimating need and coverage for five priority assistive products: a systematic review of global population-based research. BMJ Global Health 2022;7:e007662. doi:10.1136/ bmjgh-2021-007662

Handling editor Seema Biswas Received 7 October 2021 Accepted 10 December 2021

Check for updates

(C) Author(s) (or their employer(s)) 2022. Re-use permitted under CC BY-NC. No commercial re-use. See rights and permissions. Published by BMJ.

${ }^{1}$ Department of Computer Science, Global Disability Innovation Hub, University College London, London, UK ${ }^{2}$ International Centre for Evidence in Disability, London School of Hygiene and Tropical Medicine, London, UK

${ }^{3}$ Hospital das Clinicas HCFMUSP, Universidade de Sao Paulo, Sao Paulo, Brazil

${ }^{4}$ Department of Psychology, Assisted Living and Learning Institute, Maynooth University, Maynooth, Ireland

${ }^{5}$ Department of Health Sciences, Mental Health and Wellbeing, University of Warwick, Warwick, UK

Correspondence to Jamie Danemayer; jamie.danemayer.21@ucl.ac.uk

\section{ABSTRACT}

Introduction To improve access to assistive products (APs) globally, data must be available to inform evidencebased decision-making, policy development and evaluation, and market-shaping interventions. Methods This systematic review was undertaken to identify studies presenting population-based estimates of need and coverage for five APs (hearing aids, limb prostheses, wheelchairs, glasses and personal digital assistants) grouped by four functional domains (hearing, mobility, vision and cognition).

Results Data including 656 AP access indicators were extracted from 207 studies, most of which $(n=199,96 \%)$ were cross-sectional, either collecting primary $(n=167)$ or using secondary $(n=32)$ data. There was considerable heterogeneity in assessment approaches used and how AP indicators were reported; over half $(n=110)$ used a combination of clinical and self-reported assessment data. Of 35 studies reporting AP use out of all people with functional difficulty in the corresponding functional domains, the proportions ranged from $4.5 \%$ to $47.0 \%$ for hearing aids, from $0.9 \%$ to $17.6 \%$ for mobility devices, and from $0.1 \%$ to $86.6 \%$ for near and distance glasses. Studies reporting AP need indicators demonstrated $>60 \%$ unmet need for each of the five APs in most settings.

Conclusion Variation in definitions of indicators of AP access have likely led to overestimates/underestimates of need and coverage, particularly, where the relationship between functioning difficulty and the need for an AP is complex. This review demonstrates high unmet need for APs globally, due in part to disparate data across this sector, and emphasises the need to standardise AP data collection and reporting strategies to provide a comparable evidence base to improve access to APs.

\section{INTRODUCTION}

Assistive technology (AT) includes assistive products (APs) and related services that can improve health and well-being, enable increased independence and foster participation for people with functional difficulties, including older adults and people with

\section{Key questions}

What is already known?

- Access to assistive technology (AT) is limited globally, especially in low/middle-income countries (LMICs), largely due to sparse, disparate data on assistive products (APs).

- Currently, there exists no dedicated repository of population-based AP research.

- As a result, many governments lack coherent information about unmet AP need, which can hinder development of evidence-based programmes and policies to address this gap.

What are the new findings?

- The finding of high unmet need $(>60 \%)$ for each of the five APs emphasises the need to secure political prioritisation and funding to expand access to AT globally.

- Vision is proportionately overrepresented in the literature, with $76 \%$ of studies reporting all or in part on glasses. 'AP use' was reported 195 times overall ( $30 \%$ of all 656 indicators), making it the most commonly reported AP indicator from this dataset.

- Discrepancies in how key terms related to AP access were defined likely led to overestimates/underestimates of need.

What do the new findings imply?

- Synthesising disparate evidence and comparing across country contexts and functional domains provided a strong base to advocate for increasing access to APs, while identifying underrepresented regions, populations and APs.

- The evidence basis in LMICs is particularly sparse, demonstrating that knowledge gaps are widest, where AP access is the most limited.

- The development of a global minimum dataset on AP research is needed, as well as future research that disaggregates domain-specific and region-specific AP access by additional variables (eg, gender, income and education). 
impairments or chronic health conditions. ${ }^{1}$ This paper uses the umbrella term 'functional difficulty' (FD) to refer to all of these groups.

The WHO estimates 2.4 billion people globally have FD and over 1 billion need APs and related services. ${ }^{2}$ This need is expected to rise as populations age, which forecasts an increase in years lived with FD. ${ }^{2}$ Furthermore, in some low/middle-income countries (LMICs), higher prevalence of chronic and infectious disease and injuryrelated morbidity, coupled with a shortage of trained care workers, results in higher overall rates of FD and associated increased demand on healthcare, rehabilitation and AT service delivery systems. ${ }^{3}$ The SARS-CoV-2 (COVID19) pandemic has also resulted in increased FD prevalence due to disruptions of health/rehabilitation services and its direct impact on health and functioning. ${ }^{4}$ This includes 'long COVID-19', where symptoms decreasing functional abilities persist, the full impact of which is yet to be fully realised. ${ }^{56}$

Despite AT's critical relevance to all 17 sustainable development goals, the sector has not received equitable attention on the international agenda. ${ }^{7}$ Data on AP need are essential to support decision-makers to secure political prioritisation, identify causes of delivery system bottlenecks, and implement interventions to address population-level AT access. ${ }^{8}$ Information on this access is lacking, including estimates of use, unmet needs, and met needs, due in part to the complexity of assessing individuals for AP need. ${ }^{9}$ Further, due to disparate patterns of data collection, analysis, and reporting, it's often unclear what data are available and impactful data may go unused. An essential next step is, therefore, to centralise and collate available data indicating AP access and synthesise learnings across APs and functional domains to inform the sector overall.

Assistive product lists (APLs) (PAPs) are used to focus and coordinate efforts to expand AP access. Further specifying a list of priority assistive products (PAPs) at the national level is encouraged in specific countries to ensure the list is contextual and based on their unique needs. The WHO Global Cooperation on Assistive Technology's priority assistive product list presents a global list of 50 priority APs. ${ }^{10}$ Of these, ATScale, ${ }^{11}$ a Global Partnership for Assistive Technology, selected five priority APs corresponding to four functional domains: hearing aids (hearing), limb prostheses and wheelchairs (mobility), glasses (vision) and personal digital assistants (PDAs) (cognition). ${ }^{10}$

\section{Aims}

To contribute to a global effort to increase the AT evidence base, we conducted a systematic review of studies, which generated population-based AP access indicators for the five priority ATScale APs. This review aims to (1) characterise existing population-level research producing AP access indicators and (2) present and synthesise indicators globally to support scaling up AT provision.

This review builds on the findings of an initial scoping review, commissioned by the WHO and published separately, ${ }^{9}$ which primarily focused on the strengths, limitations and most effective contexts for different methods used for estimating AP supply and demand at market level in AT research. Results from these methodologies are explored in this systematic review.

\section{METHODS}

The systematic search was conducted in March 2020 and included peer-reviewed articles and grey literature with findings on APs. The Preferred Reporting Items for Systematic Reviews and Meta-Analyses statement was followed throughout review. ${ }^{12}$

\section{AP access indicators defined}

Population-level AP access indicators are variably used and defined in the literature. Table 1 shows the definitions used for the purposes of this review, developed by

Table 1 AP access indicators definitions and calculations

\begin{tabular}{|c|c|c|}
\hline AP access indicator & Working definition & Equation \\
\hline Need & $\begin{array}{l}\text { The proportion of a defined population who could benefit from using an } \\
\text { appropriate AP, based on an AP assessment approach, including those } \\
\text { already using the AP }\end{array}$ & $\begin{array}{l}\text { Population who could benefit from an } \\
\text { AP/defined population }\end{array}$ \\
\hline Has AP & $\begin{array}{l}\text { The proportion of a defined population who have an AP (obtained } \\
\text { through purchase, loan, rent, donation or by other means) }\end{array}$ & $\begin{array}{l}\text { Population who have APs/defined } \\
\text { population }\end{array}$ \\
\hline Use & The proportion of a defined population who use an AP & $\begin{array}{l}\text { Population who use APs/defined } \\
\text { population }\end{array}$ \\
\hline $\begin{array}{l}\text { Met need (population with } \\
\text { full coverage) }\end{array}$ & The proportion of a population who need and use appropriate APs & $\begin{array}{l}\text { Population who need and use } \\
\text { appropriate APs/defined population }\end{array}$ \\
\hline $\begin{array}{l}\text { Undermet need (population } \\
\text { with partial coverage) }\end{array}$ & $\begin{array}{l}\text { The proportion of a population who need and use APs that are } \\
\text { insufficient to maximise functioning }\end{array}$ & $\begin{array}{l}\text { Population who use insufficient APs/ } \\
\text { defined population }\end{array}$ \\
\hline $\begin{array}{l}\text { Unmet need (population } \\
\text { with no coverage) }\end{array}$ & The proportion of a population who need and do not use any APs & $\begin{array}{l}\text { Population who need and do not use } \\
\text { appropriate APs/defined population }\end{array}$ \\
\hline Coverage & The proportion of a defined population who need and use an AP & $\begin{array}{l}\text { Population who need and use APs/ } \\
\text { population who need APs }\end{array}$ \\
\hline
\end{tabular}

$\mathrm{AP}$, assistive product. 
drawing on authors' expertise and relevant background literature (table 1). ${ }^{9}$ These terms are referred to as 'indicators' throughout this paper.

\section{Search strategy}

Fifteen databases were searched for empirical and grey literature using a set search string specifying (1) a synonym for AP or the name of the actual AP, (2) an indicator and (3) a synonym for FD in the study's title/ abstract (online supplemental appendices 1 and 2). Studies were exported to the Rayyan QCRI web application $^{13}$ to remove duplicates and screen abstracts.

\section{Eligibility criteria}

Our search included studies published between 2000 and 2020, written originally in English, French, Portuguese, or Spanish, or providing a translation. Studies were eligible for inclusion if they met the following criteria during full text review:

- At least a portion of study data is collected since 1 January 2000.

- The study generated at least one indicator (table 1) for one of the five specified priority APs. ${ }^{10}$

- The study was a primary or secondary analysis of a representative, population-based sample.

\section{Review}

After removing duplicates, all titles and abstracts were initially screened for any mention of AT or FD. Remaining abstracts were then reviewed by two authors, according to eligibility criteria. ${ }^{9}$ In addition, eligible systematic reviews were cross-referenced; any relevant citations missing from our searches were added. All full texts were then reviewed by two authors. Conflicts at all stages were settled by a third reviewer.

\section{Data extraction and analysis}

Data were extracted from full texts and entered into a data portal designed by authors to standardise data extraction for the following: study setting, population, design, assessment methodologies, impairment definitions used, and indicators, including numerator and denominator values (online supplemental appendix 3).

Indicators were included if (1) they were directly reported in the results of studies, meaning they aligned with our terms and definitions (table 1) or (2) they were indirectly reported, meaning it was possible to calculate them using clearly defined data provided in the articles (demonstrated in online supplemental appendix 4).

Given substantial variation in how indicators are presented and reported, not all results were directly comparable and a meta-analysis could not be conducted. Where studies present pooled estimates from previously published results (eg, reviews), the unique pooled indicator was extracted. To facilitate comparison across studies where possible, indicator denominators are denoted in our results tables with the following labels:

- Total population: the broader regional or national population from which the study sample was drawn.
This denominator is larger than the number of participants when study results are only presented as extrapolations.

- Total in analysis: all participants included in the study's analysis. This may be smaller than the number of total participants reported in a study, as some participants may not complete all components of the assessments.

- Total with FD: all study participants assessed to have the relevant impairment (eg, vision impairment) or functioning difficulty (eg, difficulty seeing). Some studies only include individuals with impairment/FD as participants or in the analysis.

- Total with need: all participants assessed to have need of the relevant AP. Some studies consider all participants with impairment/FD as needing an AP.

- Total with AP: all participants who already have an AP. Most included vision AP studies reported on vision assessments done at $6 \mathrm{~m}$. Alternative definitions (eg, $20 \mathrm{ft}, \log$ MAR) were converted to $6 \mathrm{~m}$ using the NIDEK conversion chart. ${ }^{14}$ For distance vision studies, prevalence estimates for uncorrected and undercorrected refractive error were also extracted, as these equate to unmet and undermet need for glasses, respectively. Results for 'refractive error' only (ie, without specifying uncorrected or undercorrected) were not extracted.

\section{Risk of bias in individual studies}

The Critical Assessment Tool for Prevalence Studies from the Joanna Briggs Institute (JBI) was used to evaluate all included full texts. ${ }^{15}$ We adapted this tool by adding a 10th criterion: 'The study describes its ethical approval, including how consent was obtained from participants'. We present each study's summary score and specific missing checklist criteria (online supplemental appendix 5).

This review was not registered with PROSPERO due to its relation to the scoping review, ${ }^{9}$ which necessitated the extraction of some overlapping systematic review data during the scoping review process. PROSPERO does not register scoping reviews and will not register systematic reviews which have already begun data extraction.

\section{Role of the funding source}

The funder of the study had no role in study design, data collection, data analysis, data interpretation or writing of the report.

\section{Patient and public involvement}

Patients and the public were not involved in any way in this research.

\section{RESULTS}

This section first details overall study selection and characteristics. Next, results including AP indicators are presented for each AP, grouped by functional domain. 


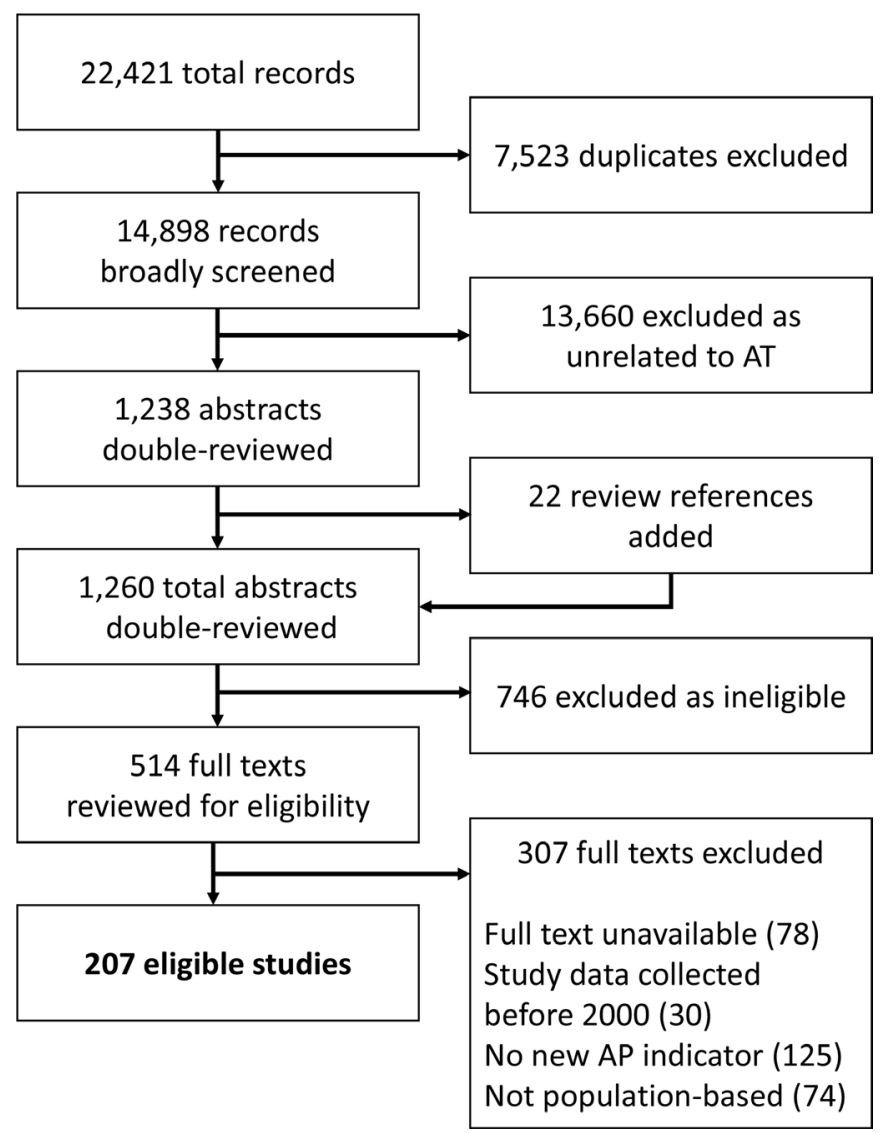

Figure 1 Study selection. AP, assistive product; AT, assistive technology.

\section{Study selection}

Of 14898 unique records identified, 1238 abstracts mentioned AT and/or FD (JD). Ten per cent $(n=1336)$ of discarded records were reviewed by a second author $(\mathrm{CH}, \mathrm{DB}$ and SP) with $100 \%$ agreement. Seven reviews were identified at this stage and cross-referenced, adding 22 abstracts (JD, DB and ES). Of 1260 total abstracts, 514 met inclusion criteria, determined by two authors (JD, $\mathrm{DB}, \mathrm{VDR}, \mathrm{SP}, \mathrm{CH}$ and ES). Following full-text review, 207 articles met inclusion criteria (with 96\% inter-rater agreement) (JD, DB, VDR and ES). Studies excluded at this stage are listed in online supplemental appendix 6 . Figure 1 details the full review process. Corresponding authors were contacted for all articles missing full texts (initially $\mathrm{n}=85$ ), resulting in seven additions (JD). All extracted data were double-checked (JD, AK, VDR, DB, ES, SP and $\mathrm{CH}$ ).

\section{Included study characteristics}

All studies were published between 2002 and 2020. The cumulative frequency of studies published each year is shown by WHO region and AP type in figure 2A,B. The most represented region was the Western Pacific Region (WPR) $(\mathrm{n}=55,27 \%)$, specifically China $(\mathrm{n}=29 / 55,53 \%)$, followed by the Region of the Americas (AMR) ( $n=50$, $24 \%)$, specifically the USA $(\mathrm{n}=27 / 50,54 \%)$ and the Southeast Asian Region (SEAR) $(\mathrm{n}=46,22 \%)$, specifically India $(\mathrm{n}=31 / 46,67 \%)$.

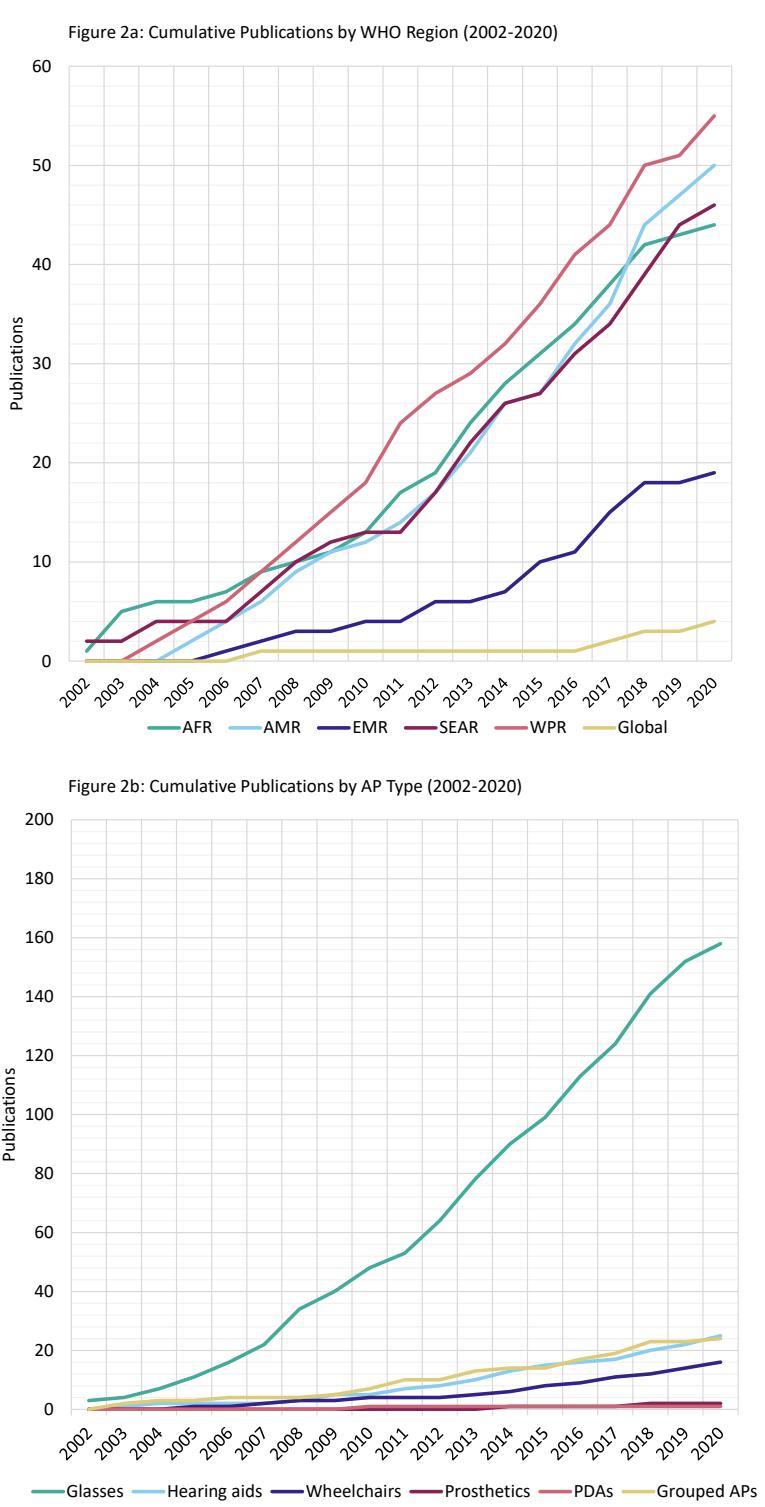

Figure 2 Cumulative publication frequency by WHO Region (A) and AP type (B). AP, assistive product; PDAs, personal digital assistants.

Figure 2B demonstrates most studies ( $\mathrm{n}=158,76 \%)$ presented indicators for glasses, compared with the other APs.

In terms of study design, the vast majority were crosssectional $(\mathrm{n}=199,96 \%)$, using primary $(\mathrm{n}=167)$ and secondary data $(\mathrm{n}=32)$. Common assessment approaches included clinical $(n=60)$, self-report $(n=37)$, or a combination of both $(\mathrm{n}=110,53 \%)$.

The youngest included age was zero (included in 27 studies) and 129 studies (62\%) included no age maximum. Nineteen studies $(9 \%)$ include most or all ages $(<3$ years to $>84$ years). Children $<13$ years are included in 91 studies overall $(44 \%)$ and 20 exclusively $(10 \%)$, while adults $>64$ years are included in 137 overall $(66 \%)$ and 13 exclusively $(6 \%)$.

The average JBI score among all 207 studies was 9.3/10, with $50 \%(\mathrm{n}=104)$ achieving all 10 checklist 
Table 2 Hearing aid studies and indicators

\begin{tabular}{|c|c|c|c|c|c|c|c|c|}
\hline Study design & Cohort & Cross-sectional & Mixed-methods & $\begin{array}{l}\text { Secondary cross- } \\
\text { sectional }\end{array}$ & - & - & - & Total \\
\hline N & 1 & 9 & 1 & 14 & - & - & - & 25 \\
\hline$\%$ & $4 \%$ & $36 \%$ & $4 \%$ & $56 \%$ & - & - & - & $100 \%$ \\
\hline $\begin{array}{l}\text { Assessment } \\
\text { approaches }\end{array}$ & $\begin{array}{l}\text { Clinical } \\
\text { only }\end{array}$ & Self-report only & Functional only & $\begin{array}{l}\text { Clinical and self- } \\
\text { report }\end{array}$ & $\begin{array}{l}\text { Clinical and } \\
\text { functional }\end{array}$ & $\begin{array}{l}\text { Other } \\
\text { combination }\end{array}$ & $\begin{array}{l}\text { Secondary } \\
\text { sources } \\
\text { (multiple) }\end{array}$ & \\
\hline N & 2 & 4 & 0 & 14 & 2 & 2 & 1 & 25 \\
\hline$\%$ & $8 \%$ & $16 \%$ & $0 \%$ & $56 \%$ & $8 \%$ & $8 \%$ & $4 \%$ & $100 \%$ \\
\hline Participants $(\mathrm{N})^{*}$ & $<500$ & 500-999 & $1000-4999$ & 5000-9999 & 10000-24999 & $>25000$ & Not available & \\
\hline N & 3 & 1 & 11 & 2 & 3 & 4 & 1 & 25 \\
\hline$\%$ & $12 \%$ & $4 \%$ & $44 \%$ & $8 \%$ & $12 \%$ & $16 \%$ & $4 \%$ & $100 \%$ \\
\hline $\begin{array}{l}\text { Age (years) } \\
\text { included } \dagger\end{array}$ & Under 15 & $<15$ to $85+$ & 15 to $85+$ & 40 to $85+$ & 65 to $85+$ & Over 85 & - & \\
\hline $\mathrm{N}$ & 1 & 7 & 5 & 4 & 7 & 1 & - & 25 \\
\hline$\%$ & $4 \%$ & $28 \%$ & $20 \%$ & $28 \%$ & $28 \%$ & $4 \%$ & - & $100 \%$ \\
\hline JBI score & $<7$ & 7 & 8 & 9 & 10 & - & - & \\
\hline N & 1 & 1 & 5 & 5 & 13 & - & - & 25 \\
\hline$\%$ & $4 \%$ & $4 \%$ & $20 \%$ & $20 \%$ & $52 \%$ & - & - & $100 \%$ \\
\hline $\begin{array}{l}\text { Functioning } \\
\text { difficulty or } \\
\text { impairment } \\
\text { definition }\end{array}$ & $\begin{array}{l}\text { Use of } \\
\text { AP }\end{array}$ & $\begin{array}{l}\text { Reported activity } \\
\text { limitations }\end{array}$ & Clinical threshold & Combination & - & - & - & \\
\hline $\mathrm{N}$ & 3 & 5 & 14 & 3 & - & - & - & 25 \\
\hline$\%$ & $12 \%$ & $20 \%$ & $56 \%$ & $12 \%$ & - & - & - & $100 \%$ \\
\hline WHO Region & AFR & AMR & EMR & EUR & SEAR & WPR & Global & \\
\hline N & 3 & 10 & 1 & 8 & 3 & 8 & 1 & 34 \\
\hline$\%$ & $9 \%$ & $29 \%$ & $3 \%$ & $24 \%$ & $9 \%$ & $24 \%$ & $3 \%$ & $100 \%$ \\
\hline $\begin{array}{l}\text { AP access } \\
\text { indicator }\end{array}$ & $\begin{array}{l}\text { Total } \\
\text { need }\end{array}$ & Met need & Unmet need & Undermet need & Coverage & Use & Has AP & \\
\hline $\mathrm{N}$ & 7 & 1 & 17 & 0 & 2 & 26 & 9 & 62 \\
\hline$\%$ & $11 \%$ & $2 \%$ & $27 \%$ & $0 \%$ & $3 \%$ & $42 \%$ & $15 \%$ & $100 \%$ \\
\hline $\begin{array}{l}\text { Indicator } \\
\text { denominator }\end{array}$ & $\begin{array}{l}\text { Total } \\
\text { with/ } \\
\text { using } \\
\text { AP }\end{array}$ & Total with need & $\begin{array}{l}\text { Total with } \\
\text { functioning difficulty }\end{array}$ & Total participants & $\begin{array}{l}\text { Total } \\
\text { population }\end{array}$ & - & - & \\
\hline$N$ & 1 & 20 & 15 & 24 & 2 & - & - & 62 \\
\hline$\%$ & $2 \%$ & $32 \%$ & $24 \%$ & $39 \%$ & $3 \%$ & - & - & $100 \%$ \\
\hline
\end{tabular}

${ }^{*}$ Participants $(\mathrm{N})$ ranged from 379 to 455200 for this domain.

†Age group boundaries varied considerably by study; studies are sorted into categories that most closely represent their included age boundaries.

AFR, African Region; AMR, Region of the Americas; AP, assistive product; EMR, Eastern Mediterranean Region; EUR, European Region; JBI, Joanna Briggs Institute; SEAR, Southeast Asian Region; WPR, Western Pacific Region.

items, and only one scoring below 7. By domain, the average JBI score ranged from 8.6 to 9.3. The most missed items were \#2 (appropriate or well-described sampling of study participants) (n=30), \#4 (study subjects and setting described in detail $) \quad(n=49)$ and our added \#10 (consent and ethical approval detailed) $(\mathrm{n}=18)$ (online supplemental appendix 5).

\section{AP access indicators}

Overall, 656 AP access indicators were extracted. Highlevel results are presented for each AP, grouped by functional domain (tables 2-5) with all indicators from each study listed in online supplemental appendices 7-11. Studies reporting data, which could be disaggregated by comparable need indicators, are also included in figure 3A-E and online supplemental appendix 12.

\section{Hearing}

In total, 25 studies (12\%) provided 62 indicators on hearing aid access, detailed in table 2 and online supplemental appendix $7 .{ }^{16-40}$ Nearly all were based on primary $(\mathrm{n}=10,40 \%)$ or secondary analyses $(\mathrm{n}=14,56 \%)$ of crosssectional studies. The majority $(\mathrm{n}=18,72 \%)$ used multiple assessment approaches, while self-report was exclusively used by $4(16 \%)$ and clinical assessment by $2(8 \%)$. All but one study ${ }^{38}$ assumed all participants identified as 
Table 3 Mobility AP studies and indicators

\begin{tabular}{|c|c|c|c|c|c|c|c|c|}
\hline Study design & Cohort & Cross-sectional & Mixed-methods & $\begin{array}{l}\text { Secondary cross- } \\
\text { sectional }\end{array}$ & - & - & - & Total \\
\hline $\mathrm{N}$ & 0 & 3 & 1 & 11 & - & - & - & 15 \\
\hline$\%$ & $0 \%$ & $20 \%$ & $7 \%$ & $73 \%$ & - & - & - & $100 \%$ \\
\hline $\begin{array}{l}\text { Assessment } \\
\text { approaches }\end{array}$ & $\begin{array}{l}\text { Clinical } \\
\text { only }\end{array}$ & Self-report only & Functional only & $\begin{array}{l}\text { Clinical and self- } \\
\text { report }\end{array}$ & $\begin{array}{l}\text { Clinical and } \\
\text { functional }\end{array}$ & $\begin{array}{l}\text { Other } \\
\text { combination }\end{array}$ & $\begin{array}{l}\text { Secondary } \\
\text { sources } \\
\text { (multiple) }\end{array}$ & \\
\hline $\begin{array}{l}\text { Participants } \\
(\mathrm{N})^{\star}\end{array}$ & $<500$ & 500-999 & 1000-4999 & 5000-9999 & 10000-24999 & $>25000$ & Not available & \\
\hline $\mathrm{N}$ & 0 & 1 & 4 & 4 & 2 & 4 & 0 & 15 \\
\hline$\%$ & $0 \%$ & $7 \%$ & $27 \%$ & $27 \%$ & $13 \%$ & $27 \%$ & $0 \%$ & $100 \%$ \\
\hline JBI score & $<7$ & 7 & 8 & 9 & 10 & - & - & \\
\hline $\mathrm{N}$ & 0 & 0 & 3 & 5 & 7 & - & - & 15 \\
\hline$\%$ & $0 \%$ & $0 \%$ & $20 \%$ & $33 \%$ & $47 \%$ & - & - & $100 \%$ \\
\hline $\begin{array}{l}\text { Mobility } \\
\text { functioning } \\
\text { difficulty or } \\
\text { impairment } \\
\text { definition }\end{array}$ & Use of AP & $\begin{array}{l}\text { Reported } \\
\text { activity } \\
\text { limitations }\end{array}$ & Clinical threshold & Combination & - & - & - & \\
\hline $\mathrm{N}$ & 7 & 6 & 0 & 2 & - & - & - & 15 \\
\hline$\%$ & $47 \%$ & $40 \%$ & $0 \%$ & $13 \%$ & - & - & - & $100 \%$ \\
\hline$\%$ & $7 \%$ & $0 \%$ & $14 \%$ & $2 \%$ & $5 \%$ & $62 \%$ & $10 \%$ & $100 \%$ \\
\hline $\begin{array}{l}\text { Indicator } \\
\text { denominator }\end{array}$ & $\begin{array}{l}\text { Total with/ } \\
\text { using AP }\end{array}$ & Total with need & $\begin{array}{l}\text { Total with } \\
\text { functioning } \\
\text { difficulty }\end{array}$ & Total participants & Total population & - & - & \\
\hline $\mathrm{N}$ & 3 & 2 & 12 & 19 & 6 & - & - & 42 \\
\hline$\%$ & $7 \%$ & $5 \%$ & $29 \%$ & $45 \%$ & $14 \%$ & - & - & $100 \%$ \\
\hline
\end{tabular}

${ }^{*}$ Participants $(\mathrm{N})$ ranged from 839 to 66410 for this domain.

†Age group boundaries varied considerably by study; studies are sorted into categories that most closely represent their included age boundaries. AFR, African Region; AMR, Region of the Americas; AP, assistive product; EMR, Eastern Mediterranean Region; EUR, European Region; JBI, Joanna Briggs Institute; SEAR, Southeast Asian Region; WPR, Western Pacific Region.

having a hearing difficulty also needed a hearing aid (ie, prevalence of hearing difficulty equals hearing aid need were the same). The proportion of participants with hearing difficulty who were using hearing aids ranged from $4.5 \%{ }^{38}$ to $47.5 \%,{ }^{34}$ although the definition of hearing difficulty varied between these studies (online supplemental appendix 7). Ten studies across 17 settings informed on total need. Figure 3A demonstrates high unmet need for hearing aids, with most settings $(n=16$, $89 \%$ ) showing over $60 \%$ unmet need (ie, $>60 \%$ of people assessed to need a hearing aid did not have one). All of these studies reported unmet need, but only one also reported met need ${ }^{33}$ while the others substituted AP use.

\section{Mobility}

Fifteen studies $(7 \%)$ reported 42 access indicators for mobility APs, including prosthetics, motorised and manual wheelchairs. Characteristics are included in table 3 and all indicators in online supplemental appendix 8. ${ }^{17} 2225273040-49$ Most mobility AP studies $(\mathrm{n}=11,73 \%)$ were secondary analyses of nationallevel surveys/censuses. Six studies relied entirely on 
Table 4 Near and distance glasses studies and indicators

\begin{tabular}{|c|c|c|c|c|c|c|c|c|c|c|}
\hline Study design & Cohort & $\begin{array}{l}\text { Cross- } \\
\text { sectional }\end{array}$ & $\begin{array}{l}\text { Mixed- } \\
\text { methods }\end{array}$ & $\begin{array}{l}\text { Secondary } \\
\text { cross- } \\
\text { sectional }\end{array}$ & - & - & - & - & - & Total \\
\hline $\mathrm{N}$ & 1 & 46 & 0 & 5 & - & - & - & - & - & 52 \\
\hline $\begin{array}{l}\text { Assessment } \\
\text { approaches }\end{array}$ & Clinical only & $\begin{array}{l}\text { Self-report } \\
\text { only }\end{array}$ & $\begin{array}{l}\text { Functional } \\
\text { only }\end{array}$ & $\begin{array}{l}\text { Clinical and } \\
\text { self-report }\end{array}$ & $\begin{array}{l}\text { Clinical and } \\
\text { functional }\end{array}$ & $\begin{array}{l}\text { Other } \\
\text { combination }\end{array}$ & $\begin{array}{l}\text { Secondary } \\
\text { sources } \\
\text { (multiple) }\end{array}$ & - & - & \\
\hline Participants $(\mathrm{N})^{\star}$ & $<500$ & 500-999 & 1000-4999 & 5000-9999 & $\begin{array}{l}10000-24 \\
999\end{array}$ & $>25000$ & Not available & - & - & \\
\hline N & 3 & 6 & 24 & 10 & 6 & 2 & 1 & - & - & 52 \\
\hline$\%$ & $6 \%$ & $12 \%$ & $46 \%$ & $19 \%$ & $12 \%$ & $4 \%$ & $2 \%$ & - & - & $100 \%$ \\
\hline $\begin{array}{l}\text { Age (years) } \\
\text { Included } \dagger\end{array}$ & Under 15 & $<15$ to $85+$ & 15 to $85+$ & 40 to $85+$ & 60 to $85+$ & Over 85 & Other & - & - & \\
\hline JBI score & $<7$ & 7 & 8 & 9 & 10 & - & - & - & - & \\
\hline N & 0 & 1 & 5 & 19 & 27 & - & - & - & - & 52 \\
\hline$\%$ & $0 \%$ & $2 \%$ & $10 \%$ & $37 \%$ & $52 \%$ & - & - & - & - & $100 \%$ \\
\hline $\begin{array}{l}\text { Vision } \\
\text { functioning } \\
\text { difficulty or } \\
\text { impairment } \\
\text { definition }\end{array}$ & Use of AP & $\begin{array}{l}\text { Reported } \\
\text { activity } \\
\text { limitations }\end{array}$ & $\begin{array}{l}\text { Clinical } \\
\text { threshold }\end{array}$ & Combination & - & - & - & - & - & \\
\hline $\mathrm{N}$ & 1 & 0 & 44 & 7 & - & - & - & - & - & 52 \\
\hline$\%$ & $2 \%$ & $0 \%$ & $85 \%$ & $13 \%$ & - & - & - & - & - & $100 \%$ \\
\hline WHO Region & AFR & AMR & EMR & EUR & SEAR & WPR & Global & - & - & \\
\hline $\mathrm{N}$ & 10 & 58 & 61 & 81 & 22 & 1 & - & - & - & 233 \\
\hline$\%$ & $4 \%$ & $25 \%$ & $26 \%$ & $35 \%$ & $9 \%$ & $0 \%$ & - & - & - & $100 \%$ \\
\hline
\end{tabular}

*Participants $(\mathrm{N})$ ranged from 134 to 3983541 for this domain.

†Age group boundaries varied considerably by study; studies are sorted into categories that most closely represent their included age boundaries.

AFR, African Region; AMR, Region of the Americas; AP, assistive product; EMR, Eastern Mediterranean Region; EUR, European Region; JBI, Joanna Briggs Institute; RE, Refractive Error; SEAR, Southeast Asian Region; WPR, Western Pacific Region.

self-reported assessment of activity limitation and/or AP need and seven used self-reported AP use to approximate functioning difficulty or impairment prevalence. AP use was the most reported indicator $(n=26 / 42,62 \%)$. Among the total with mobility difficulty, use of any type of mobility AP ranged from $0.9 \%$ (both prosthetics and motorised wheelchairs) ${ }^{30}$ to $17.6 \%$ (manual/unspecified wheelchairs) (online supplemental appendix 8). ${ }^{45}$ Only one clinical impairment assessment study ${ }^{22}$ presented AP indicators allowing disaggregation of total need, showing high unmet need $(>65 \%)$ for manual wheelchairs in two settings among those who needed the AP (figure 3C).

\section{Vision}

Vision results are presented in three categories: near/ reading glasses $(n=35)$, distance glasses $(n=31)$ and bifocal/combined/unspecified ('grouped') glasses $(n=124)$. High-level results for near and distance glasses are combined in table 4 , with specific results for each type described separately in-text. All included studies and indicators are available for near and distance glasses in online supplemental appendix $9^{22}$ 50-100 and grouped glasses in online supplemental appendix $10 .^{2730} 4051-5562-657276788081848695101-202$ Need indicators for grouped glasses are also visualised in online supplemental appendix 12 . 
Table 5 Grouped and cognitive AP studies and indicators

Study design Cohort Cross-sectional Mixed-methods

Secondary cross- -

sectional

\begin{tabular}{|c|c|c|c|c|c|c|c|c|}
\hline $\mathrm{N}$ & 0 & 17 & 1 & 6 & - & - & - & 24 \\
\hline$\%$ & $0 \%$ & $71 \%$ & $4 \%$ & $25 \%$ & - & - & - & $100 \%$ \\
\hline $\begin{array}{l}\text { Assessment } \\
\text { approaches }\end{array}$ & $\begin{array}{l}\text { Clinical } \\
\text { only }\end{array}$ & Self-report only & Functional only & $\begin{array}{l}\text { Clinical and self- } \\
\text { report }\end{array}$ & $\begin{array}{l}\text { Clinical and } \\
\text { functional }\end{array}$ & $\begin{array}{l}\text { Other } \\
\text { combination }\end{array}$ & $\begin{array}{l}\text { Secondary } \\
\text { sources } \\
\text { (multiple) }\end{array}$ & \\
\hline $\mathrm{N}$ & 1 & 21 & 0 & 1 & 0 & 1 & 0 & 24 \\
\hline$\%$ & $4 \%$ & $88 \%$ & $0 \%$ & $4 \%$ & $0 \%$ & $4 \%$ & $0 \%$ & $100 \%$ \\
\hline $\begin{array}{l}\text { Participants } \\
(\mathrm{N})^{\star}\end{array}$ & $<500$ & 500-999 & 1000-4999 & 5000-9999 & 10000-24999 & $>25000$ & $\begin{array}{l}\text { Not } \\
\text { available }\end{array}$ & \\
\hline $\mathrm{N}$ & 0 & 3 & 7 & 5 & 5 & 4 & 0 & 24 \\
\hline$\%$ & $0 \%$ & $13 \%$ & $29 \%$ & $21 \%$ & $21 \%$ & $17 \%$ & $0 \%$ & $100 \%$ \\
\hline $\begin{array}{l}\text { Age (years) } \\
\text { included } t\end{array}$ & Under 15 & $<15$ to $85+$ & 15 to $85+$ & 40 to $85+$ & 60 to $85+$ & Over 85 & Other & \\
\hline $\mathrm{N}$ & 0 & 16 & 5 & 0 & 2 & 0 & 1 & 24 \\
\hline$\%$ & $0 \%$ & $67 \%$ & $21 \%$ & $8 \%$ & $8 \%$ & $0 \%$ & $4 \%$ & $100 \%$ \\
\hline JBI score & $<7$ & 7 & 8 & 9 & 10 & - & - & \\
\hline $\mathrm{N}$ & 0 & 2 & 5 & 10 & 7 & - & - & 24 \\
\hline$\%$ & $0 \%$ & $8 \%$ & $21 \%$ & $42 \%$ & $29 \%$ & - & - & $100 \%$ \\
\hline $\begin{array}{l}\text { Functioning } \\
\text { difficulty or } \\
\text { impairment } \\
\text { definition }\end{array}$ & $\begin{array}{l}\text { Use of } \\
\text { AP }\end{array}$ & $\begin{array}{l}\text { Reported activity } \\
\text { limitations }\end{array}$ & Clinical threshold & Combination & - & - & - & \\
\hline $\mathrm{N}$ & 3 & 21 & 0 & 0 & - & - & - & 24 \\
\hline$\%$ & $13 \%$ & $88 \%$ & $0 \%$ & $0 \%$ & - & - & - & $100 \%$ \\
\hline WHO Region & AFR & AMR & EMR & EUR & SEAR & WPR & Global & \\
\hline $\mathrm{N}$ & 14 & 7 & 1 & 0 & 2 & 1 & 0 & 25 \\
\hline$\%$ & $56 \%$ & $28 \%$ & $4 \%$ & $0 \%$ & $8 \%$ & $4 \%$ & $0 \%$ & $100 \%$ \\
\hline $\begin{array}{l}\text { AP access } \\
\text { indicator }\end{array}$ & $\begin{array}{l}\text { Total } \\
\text { need }\end{array}$ & Met need & Unmet need & Undermet need & Coverage & Use & Has AP & \\
\hline $\mathrm{N}$ & 2 & 4 & 9 & 1 & 0 & 24 & 2 & 42 \\
\hline$\%$ & $5 \%$ & $10 \%$ & $21 \%$ & $2 \%$ & $0 \%$ & $57 \%$ & $5 \%$ & $100 \%$ \\
\hline $\begin{array}{l}\text { Indicator } \\
\text { denominator }\end{array}$ & $\begin{array}{l}\text { Total } \\
\text { with/ } \\
\text { using AP }\end{array}$ & Total with need & $\begin{array}{l}\text { Total with } \\
\text { functioning } \\
\text { difficulty }\end{array}$ & Total participants & $\begin{array}{l}\text { Total } \\
\text { population }\end{array}$ & - & - & \\
\hline $\mathrm{N}$ & 1 & 5 & 28 & 8 & 0 & - & - & 42 \\
\hline$\%$ & $2 \%$ & $12 \%$ & $67 \%$ & $19 \%$ & $0 \%$ & - & - & $100 \%$ \\
\hline
\end{tabular}

*Participants $(\mathrm{N})$ ranged from 505 to 393949 for this domain.

†Age group boundaries varied considerably by study; studies are sorted into categories that most closely represent their included age boundaries.

AFR, African Region; AMR, Region of the Americas; AP, assistive product; EMR, Eastern Mediterranean Region; EUR, European Region; JBI, Joanna Briggs Institute; SEAR, Southeast Asian Region; WPR, Western Pacific Region.

Thirty-five studies (17\%) provided 126 indicators for near glasses (table 4). Most were primary cross-sectional $(\mathrm{n}=32$; $91 \%)$ and used a combination of clinical and self-reported assessment data $(\mathrm{n}=22 ; 63 \%)$, while $11(31 \%)$ used clinical assessment data only. The most reported indicators were unmet $(\mathrm{n}=49 ; 38 \%)$ and met need $(\mathrm{n}=30 ; 24 \%)$. Near glasses use among individuals with vision difficulty ranged from $0.1 \%{ }^{64}$ to $89.5 \%$ (online supplemental appendix 9 ). ${ }^{83}$ Twenty-one studies $(60 \%)$ reported total need indicators, with 17 showing unmet need for near glasses above $60 \%$ among those who needed the AP (figure 3C).

Thirty-one studies (14\%) report 107 indicators for distance glasses (table 4). All studies are either primary $(\mathrm{n}=21,81 \%)$ or secondary $(\mathrm{n}=5 ; 19 \%)$ analyses of crosssectional surveys. Sixteen studies (53\%) used both clinical and self-reported assessments, with $11(37 \%)$ relying only on clinical assessment. The most reported indicator was uncorrected refractive error $(n=35 / 107 ; 33 \%)$. Among those with 
Need Indicators: Hearing Aids

Vuorialho et al, 2004 Finland (0-100)

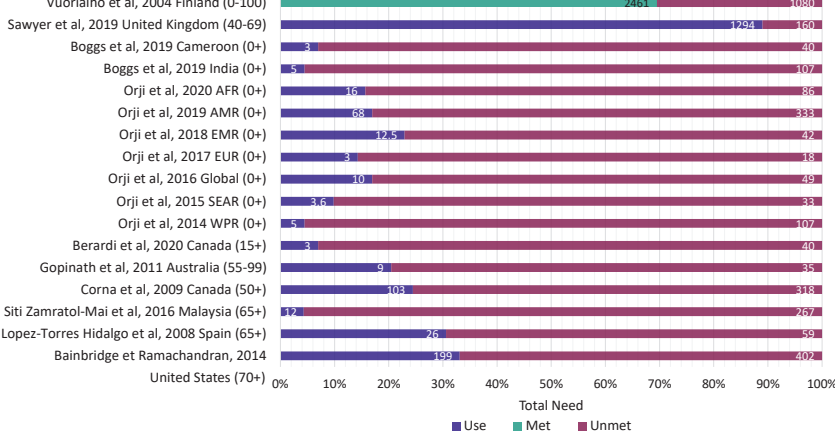

Need Indicators: Manual Wheelchairs

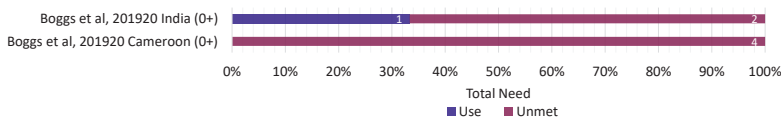

Need Indicators: Near Glasses

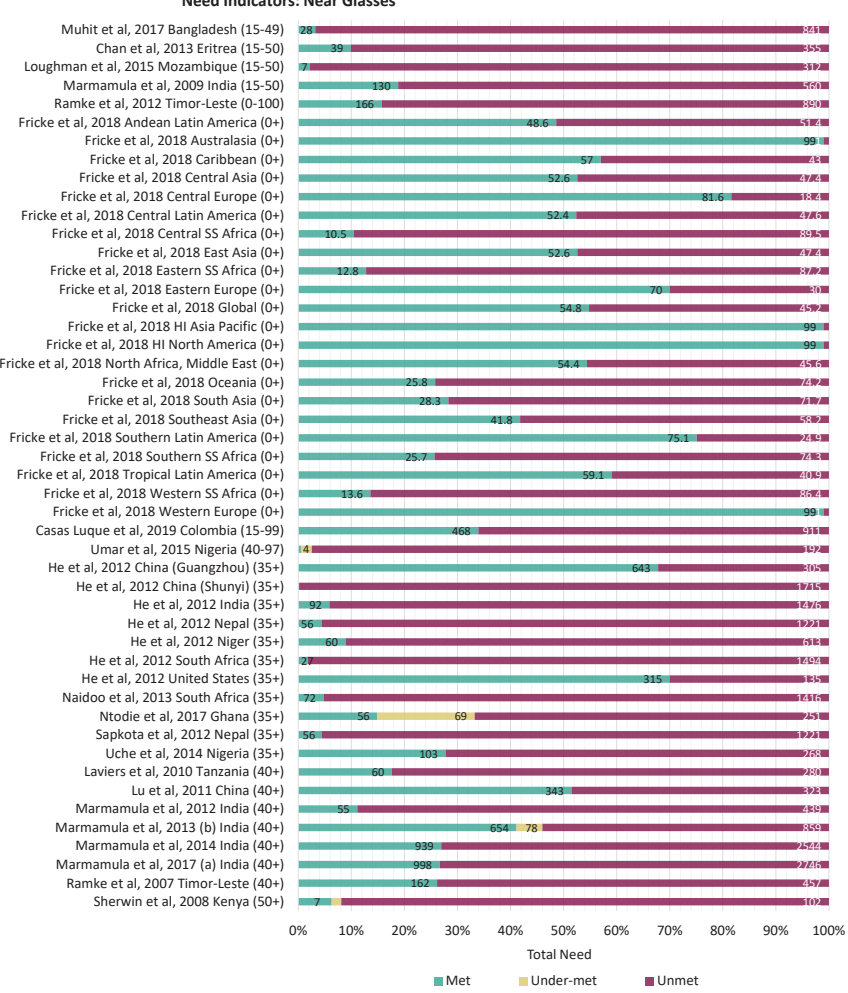

Need Indicators: Distance Glasses

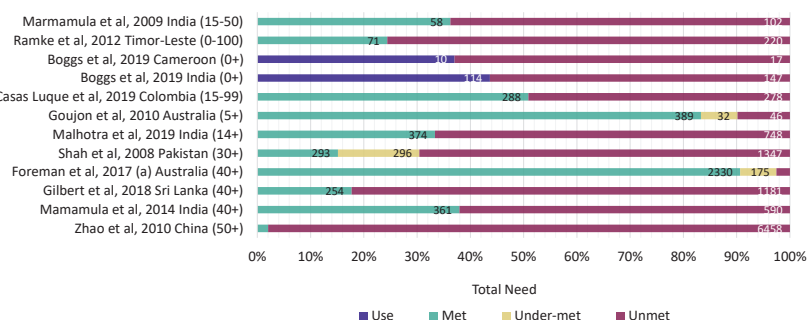

Need Indicators: Grouped AP

Danquah et Brus, 2014 Haiti (5-) Marella et al, 2016 Philippines (18-100) Matter et Eide, 2018 Botswana (15+)

Pryor et al, 2018 Bangladesh (18+)

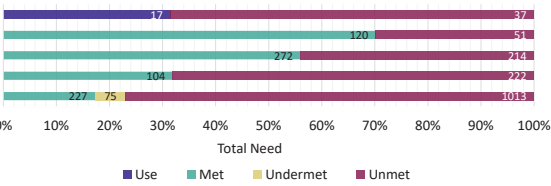

Figure 3 Need indicators for hearing aids (A), manual wheelchairs (B), near glasses (C), distance glasses (D) and grouped APs (E). HI, High-Income; SS, Sub-Saharan. 
difficulty seeing, use of distance glasses ranged from $0.4 \%^{64}$ to $55.2 \%^{87}$ (online supplemental appendix 9). Eleven studies provided total need indicators across 12 settings, the majority $(n=8 / 12 ; 67 \%)$ of which reported an unmet need for distance glasses of $>60 \%$ among those who needed the AP (figure 3D).

\section{Grouped APs and cognitive}

Twenty-four studies (12\%) presented 42 indicators for grouped APs, with one study also presenting a cognitive AP indicator for $\mathrm{PDAs}^{203}$; characteristics for all grouped AP studies are described in table 5 with all indicators included in online supplemental appendix 11. ${ }^{1725} 2730203-222$ Nearly all ( $\left.\mathrm{n}=21 ; 88 \%\right)$ used only selfreported activity limitations to identify impairment or FD. 'AP use' was the most commonly reported indicator in the grouped domain $(n=24 / 42,57 \%)$, with the proportion of participants with FD using any AP ranging from $2.8 \%{ }^{217}$ to $94.8 \%$ (online supplemental appendix 11 ). ${ }^{27}$ In three of five studies presenting total need indicators, unmet need for APs was $>60 \%$ among those who needed APs (figure 3E).

\section{DISCUSSION}

AT is gaining recognition on the international global health agenda, as evidenced in this systematic review by the increasing frequency of publications from 2000 to 2020. However, many data gaps have not been addressed. During this period, $76 \%(n=158)$ of the 207 articles reported all or in part on glasses, with fewer articles available for the other APs, emphasising data gaps in hearing, mobility and especially cognitive functional domains. Older adults (65+ years) were more often included in studies than children under 12 years, and $<25 \%$ of studies focused exclusively on young children, making it challenging to identify disparities in AP need based on age. This review also highlights the heterogeneity in study design and reporting that has led to a lack of standardisation in population-based AP data collection efforts and limits comparability between settings. Total need indicators were reported from 84 study settings, the majority of which $(\mathrm{n}=57 / 84,68 \%)$ reported unmet need $>60 \%$ among all participants with AP need in each functional domain and in all country income contexts. Total need estimates were also commonly reported across all functional domains except mobility, though functional domains were not equally represented in these studies.

AP indicators were often used variably in the literature. The prevalence of FD was frequently equated to AP need, which can overestimate/underestimate true need and coverage. $^{22}$ This approach typically lacks a holistic assessment of AP need since it does not account for important data about an individual's personal factors, including their specific health needs, activities, participation and environmental contexts. All but one mobility study ${ }^{22}$ made this assumption and relied solely on self-reported assessments, which can be limited by participants' poor awareness of APs or underlying causes for FD, further misestimating need. ${ }^{92}$ 'Has AP' or 'use' were also used to approximate 'met need' for an AP; all hearing aid studies indicating need reported 'use' in lieu of met need (excepting one ${ }^{18}$ ). This substitution limits understanding of AP need in multiple ways: in the literature, the 'use' indicator has included the use of APs that are appropriate ('met need') and APs that might be broken and/ or inappropriate ('undermet need'), which obfuscates remaining need. Denominators used when calculating indicators also varied considerably, encompassing individuals with need, functioning difficulty, included in the study, or extrapolated to the total population. Though the latter can provides useful measures for drawing international comparisons and evaluating trends over time, the variation in denominators overall limits comparability across studies. Each has its use in a comprehensive evidence basis, but more comparable methodology and reporting are needed to improve understanding of population-level need.

Self-reported assessments were typically employed in functional domains where a large sample size was needed and/or the relationship between the individual's need and a specific AP is complex (eg, mobility or cognition), or multiple APs were considered (eg, grouped APs). Subsequently, clinical impairment and/or functional assessment for all participants was often not feasible. For example, most of the reviewed mobility studies were secondary data analyses, with over half using censuses or national health studies $(n=10 / 15 ; 67 \%)$, while mobility studies that collected primary data tended to have very low numbers of individuals assessed as needing or already using the AP, ranging from $0^{22}$ to $186^{40}$ individuals. Additionally, most studies reporting on grouped APs relied exclusively on self-reported assessment data $(n=21 / 24$; $88 \%$ ). Clinical impairment assessments produce more standardised, comparable data, yet do not always capture personal factors, which are also necessary to holistically evaluate need. This demonstrates the importance of employing multiple types of data in recommending appropriate AT. ${ }^{9}$

While some established datasets based on universal $\operatorname{care}^{18} /$ centralised health record systems ${ }^{46}$ collect potentially impactful population-level data on AP users, these data do not necessarily include everyone. Relying exclusively on these data would miss individuals obtaining their APs by other means, such as private purchase or through the non-government sector. This missing data gap will be even more pronounced where government-led AT provision is more limited. Primary cross-sectional surveys can be helpful to address this gap, yet these surveys can be resource intensive, lack comparability and generalisability, and may not produce timely data needed by AT stakeholders. Our literature presents $>150$ studies from LMICs, which generate valuable learnings across the sector overall. However, when narrowing to AP-specific or country-specific data, the evidence base drastically decreases, showing the limitations of relying exclusively on few cross-sectional surveys 
and demonstrates that the largest knowledge gaps are in areas where access to APs is lowest.

Collating this critical body of work to extract sectorwide learnings has been broached, in parts, by other reviews commissioned by the Lancet Global Health, ${ }^{224}$ the $\mathrm{WHO},{ }^{39}{ }^{225}$ and development-focused institutes/ governmental departments. ${ }^{226227}$ The WHO papers cited heterogeneous approaches to assessment, ${ }^{39}{ }^{225}$ severity of FD for inclusion, ${ }^{9225}$ and sampling source demographics, ${ }^{3} 9225$ as main challenges to interpreting results across publications, which mirrored our data extraction and presentation experiencePopulation-level data are overall extremely limited, and findings on need must be interpreted with caution. Appropriate research methods must also be used for this sector-RCTs are often unsuitable for AT interventions, ${ }^{3}$ and based on available data, different approaches may be more effective than others. ${ }^{9}$ Key gaps in the AT sector described in this discussion are emphasised when considering other AT reviews. Crucial research into effectiveness and follow-up of AT interventions is limited. ${ }^{39225-227}$ Our review similarly found this, as most primary and secondary studies were cross-sectional and did not incorporate any follow-up data collection. Limited awareness of AT demand and effectiveness was a commonly cited barrier to expanding AT production and access. ${ }^{226}{ }^{227}$ Often, available data go unused ${ }^{226}$ or are not collected alongside quality-of-life indicators. ${ }^{226}$ Furthermore, standardised impact measurement approaches are also needed. ${ }^{39226}$ Regarding all types of information relevant to AT, including need indicators, supply and demand data, and product designs, more substantial diffusion is hindered by the fragmented nature of available information. ${ }^{226}$

We have four main recommendations following our comprehensive review. First, considering the methodological and reporting variation between studies, we recommend establishing a global minimum AP dataset allowing researchers to address specific questions and compare evidence. This dataset should include the following: (1) standardised measures to determine individual need for an AP; (2) standardised APs (eg, APLs); ${ }^{10} 228$ (3) standardised AP access indicators (as presented in this review) and (4) standardised approaches to measuring them. Second, we recommend the collection and use of data that holistically considers an individual's personal and environmental factors when assessing their capacity to benefit from an AP. As more holistic measurement methodology is developed, it is critical that it is tested and adapted for diverse contexts, especially LMICs. Third, modules collecting data to inform AP indicators should be included in established population surveys to maximise existing data collection methods and enable more nuanced secondary analyses. This can be supported by working with national statistics offices in both high and LMIC countries. Finally, differentiation should be made between the total using an AP, and within that value, the total with met need. This can highlight undermet needs among AP users, which provides further data about the setting and/or population for which specific APs are not fully appropriate. To begin to collate this dataset, a global AT data portal ${ }^{29}$ accompanying this review will make all extracted study data available and more accessible. This portal will also serve as a place to host future data, employing features to map evidence and provide context across disciplines to support knowledge sharing in this sector.

Our large-scale review captured $>200$ studies and benefitted from including five APs across four functional domains, with a broadly inclusive search string and list of article sources. Data extraction criteria were developed to accommodate substantial variation in results reporting, so as much relevant data as possible could be considered, allowing us to extract $>650$ indicators. Through data extraction, we identified study settings, impairment/FD thresholds and denominators (among other factors) to ensure our comparisons and conclusions are appropriate.

However, this review has several limitations. Given the breadth of literature, we searched terms for FD rather than listing specific health conditions (online supplemental appendix 2), as there is no established list of conditions within each domain/relevant to each AP. Studies may have been missed that focused on specific health conditions without mentioning FD or APs in the title/abstract. This likely occurred for the mobility and cognitive domains, given these are less well defined in terms of which conditions could relate to certain APs. This also means we could not explore the variation in need for APs within a functional domain by certain conditions or pathologies. We also limited the review to five specific APs, while the WHO APL includes 50. Furthermore, a meta-analysis of indicators and exploration into their disaggregation by demographic factors (eg, sex, income, and education) was precluded from the remit of this review due to wide variation in methods/ reporting. Finally, some vision studies also reported visual acuity measures, but extracting indicators based on these measures required clinical judgements and assumptions outside the remit of this review. Overall, future domainspecific research is recommended to address each of these limitations, including additional cognitive APs, with appropriate detail to identify sub-population-level disparities in AP access.

\section{CONCLUSION}

This review highlights high unmet AP need across different settings, demonstrating the need to prioritise and expand access to AT globally. It also highlighted key AP research gaps in available literature, including lack of standardised and comparable data collection and reporting methods, particularly in LMICs. These gaps must be addressed so data collection efforts can identify areas with high need and inform, monitor, and evaluate AP service planning and delivery. Improving global access to these life-changing products is essential to each sustainable development goal and our accompanying 
data portal ${ }^{229}$ will ensure this review is used to its fullest potential in support of this aim.

Twitter Dorothy Boggs @boggs_dorothy

Acknowledgements Authors are grateful to the help of many colleagues: Priya Morjaria and lan McCormick for visual acuity expertise and Ben Duke for preliminary data extraction.

Contributors This research was conceptualised by JD and $\mathrm{CH}$, with funding acquired by $\mathrm{CH}$. The investigation was conducted by JD, with input from DB, SP and $\mathrm{CH}$. JD, DB, SP, VDR, ES and $\mathrm{CH}$ are responsible for the methodology. FR is responsible for project administration. JD and WB are responsible for software design and maintenance. Data curation was done by JD, DB, VDR, ES and AK. Formal analysis was carried out by JD with input from DB and SP. Data were validated by JD, AK, VDR, ES, SP, DB and CH. Visualisations were designed and executed by JD, with input from DB and SP. The original draft was written by JD with input from DB and SP. Reviewing and editing was done by JD, DB, SP, VDR, ES and $\mathrm{CH}$, with input from $\mathrm{AK}$ and $\mathrm{FR}$. The overall project was supervised by DB, SP and $\mathrm{CH}$. JD is acting as guarantor.

Funding The research in this paper was made possible by funding from the Foreign, Commonwealth and Development Office, UK, through the AT2030 Programme, led by the Global Disability Innovation Hub (project number: 300815 (previously $201879-108)$ ).

Competing interests None declared.

Patient consent for publication Not applicable.

Ethics approval Ethical approval was not required for this review.

Provenance and peer review Not commissioned; externally peer reviewed.

Data availability statement Data are available in a public, open access repository. All data relevant to the study are included in the article or uploaded as supplementary information. The study protocol is currently available at https:// at2030.org/estimating-need-and-coverage-for-five-priority-assistive-products/. All data extracted for this review will be publicly available in the AT Data Portal, available at https://at2030.org/at-data-portal/map/ from March 2022.

Supplemental material This content has been supplied by the author(s). It has not been vetted by BMJ Publishing Group Limited (BMJ) and may not have been peer-reviewed. Any opinions or recommendations discussed are solely those of the author(s) and are not endorsed by BMJ. BMJ disclaims all liability and responsibility arising from any reliance placed on the content. Where the content includes any translated material, BMJ does not warrant the accuracy and reliability of the translations (including but not limited to local regulations, clinical guidelines, terminology, drug names and drug dosages), and is not responsible for any error and/or omissions arising from translation and adaptation or otherwise.

Open access This is an open access article distributed in accordance with the Creative Commons Attribution Non Commercial (CC BY-NC 4.0) license, which permits others to distribute, remix, adapt, build upon this work non-commercially, and license their derivative works on different terms, provided the original work is properly cited, appropriate credit is given, any changes made indicated, and the use is non-commercial. See: http://creativecommons.org/licenses/by-nc/4.0/.

\section{ORCID iDs}

Jamie Danemayer http://orcid.org/0000-0002-0060-5160

Dorothy Boggs http://orcid.org/0000-0001-5380-2785

Felipe Ramos-Barajas http://orcid.org/0000-0001-8729-2971

\section{REFERENCES}

1 WHO. Health systems strengthening glossary, 2011. Available: https://www.who.int/healthsystems/Glossary_January2011.pdf

2 Cieza A, Causey K, Kamenov K, et al. Global estimates of the need for rehabilitation based on the global burden of disease study 2019: a systematic analysis for the global burden of disease study 2019. Lancet 2021;396:2006-17.

3 Matter R, Harniss M, Oderud T, et al. Assistive technology in resource-limited environments: a scoping review. Disabil Rehabil Assist Technol 2017:12:105-14.

4 Prvu Bettger J, Thoumi A, Marquevich V, et al. COVID-19: maintaining essential rehabilitation services across the care continuum. BMJ Glob Health 2020;5:e002670.
5 Rajan S, Khunti K, Alwan N. In the wake of the pandemic: preparing for long COVID. World Health Organization, 2021.

6 Briggs A, Vassall A. Count the cost of disability caused by COVID-19. Nature 2021:593:502-5.

7 Tebbutt E, Brodmann R, Borg J, et al. Assistive products and the sustainable development goals (SDGs). Global Health 2016;12:1-6.

8 Savage M, Tyler N, Seghers F. Applying market shaping approaches to increase access to assistive technology: summary of the wheelchair product narrative, 2019.

9 Danemayer J, Boggs D, Polack S, et al. Measuring assistive technology supply and demand: a scoping review. Assist Technol 2021;33:35-49.

10 WHO. Priority assistive products list (APL): improving access to assistive technology for everyone, everywhere. Geneva, 2016.

11 ATscale global partnership. Available: https://atscale2030.org/ [Accessed 12 Nov 2021].

12 Page MJ, McKenzie JE, Bossuyt PM, et al. The PRISMA 2020 statement: an updated guideline for reporting systematic reviews. BMJ 2021;372:n71.

13 Ouzzani M, Hammady H, Fedorowicz Z, et al. Rayyan-a web and mobile APP for systematic reviews. Syst Rev 2016;5:210.

14 NIDEK Co. Conversion table for representation of visual acuity. Available: https://www.nidek-intl.com/visual_acuity.html [Accessed 19 Jul 2021].

15 University of Adelaide. Critical appraisal tools | Joanna Briggs Institute, 2020. Available: https://jbi.global/critical-appraisal-tools [Accessed 12 Jul 2021].

16 Muga E. Screening for disability in a community: the 'ten questions' screen for children, in Bondo, Kenya. Afr Health Sci 2003;3:33-9.

17 Vos T, Allen C, Arora M, et al. Global, regional, and national incidence, prevalence, and years lived with disability for 310 diseases and injuries, 1990-2015: a systematic analysis for the global burden of disease study 2015. The Lancet 2016;388:1545-602.

18 Vuorialho A, Sorri M, Nuojua I. Costs of hearing aid rehabilitation in two Finnish hearing centres. Audiol Med 2004:2:236-40.

19 Nash SD, Cruickshanks KJ, Huang G-H, et al. Unmet hearing health care needs: the Beaver dam offspring study. Am J Public Health 2013;103:1134-9.

20 Dawes P, Fortnum H, Moore DR, et al. Hearing in middle age: a population snapshot of 40- to 69-year olds in the United Kingdom. Ear Hear 2014;35:e44-51.

21 Sawyer CS, Armitage CJ, Munro KJ, et al. Correlates of hearing aid use in UK adults: self-reported hearing difficulties, social participation, living situation, health, and demographics. Ear Hear 2019:40:1061-8.

22 Boggs D, Kuper H, Mactaggart I. Estimating assistive technology need through population-based surveys: an analysis of data from Cameroon and India. In: Layton N, Borg J, eds. Global perspectives on assistive technology: proceedings of the GReAT Consultation. World Health Organization, 2019: 52-78.

23 Orji A, Kamenov K, Dirac M, et al. Global and regional needs, unmet needs and access to hearing AIDS. Int $J$ Audiol 2020;59:166-72.

24 Gondim LMA, Balen SA, Zimmermann KJ, et al. Study of the prevalence of impaired hearing and its determinants in the city of Itajaí, SANTA Catarina state, Brazil. Braz J Otorhinolaryngol 2012;78:27-34.

25 Danquah L, Brus A. Representation and evaluation of disability in Haiti (Port-au-Prince 2012. London, UK, 2013.

26 von Gablenz P, Hoffmann E, Holube I. Prevalence of hearing loss in northern and southern Germany. HNO 2017;65:130-5.

27 Berardi A, Smith EM, Miller WC. Assistive technology use and unmet need in Canada. Disabil Rehabil Assist Technol 2021;16:851-6.

28 Angara P, Tang DC, Snapp H. Factors associated with delayed hearing evaluation in US adults. Otolaryngol Head Neck Surg 2018;159:P268

29 Li C-M, Zhao G, Hoffman HJ, et al. Hearing disability prevalence and risk factors in two recent national surveys. Am J Prev Med 2018:55:326-35.

30 Pryor W, Nguyen L, Islam QN, et al. Unmet needs and use of assistive products in two districts of Bangladesh: findings from a household survey. Int J Environ Res Public Health 2018:15:1-13.

31 Moon IJ, Baek SY, Cho Y-S. Hearing aid use and associated factors in South Korea. Medicine 2015;94:e1580.

32 Gopinath B, Schneider J, Hartley D, et al. Incidence and predictors of hearing aid use and ownership among older adults with hearing loss. Ann Epidemiol 2011;21:497-506. 
33 Corna LM, Wade TJ, Streiner DL, et al. Corrected and uncorrected hearing impairment in older Canadians. Gerontology 2009;55:468-76.

34 Mitchell P, Gopinath B, Wang JJ, et al. Five-Year incidence and progression of hearing impairment in an older population. Ear Hear 2011;32:251-7.

$35 \mathrm{Kim} \mathrm{J-S.} \mathrm{Prevalence} \mathrm{and} \mathrm{factors} \mathrm{associated} \mathrm{with} \mathrm{hearing} \mathrm{loss}$ and hearing aid use in Korean elders. Iran J Public Health 2015;44:308-17.

36 SZMS M, Maamor N, Ishak WS. Hearing loss and risk factors among community Dwelling older adults in Selangor (Hilang Pendengaran DAN Faktor Risiko dalam Kalangan Warga Tua dalam Komuniti di Selangor). Sains Malaysiana 2016;45:1405-11.

37 Chang H-P, Ho C-Y, Chou P. The factors associated with a self-perceived hearing handicap in elderly people with hearing impairment--results from a community-based study. Ear Hear 2009;30:576-83.

38 López-Torres Hidalgo J, Boix Gras C, Téllez Lapeira J, et al. Functional status of elderly people with hearing loss. Arch Gerontol Geriatr 2009:49:88-92.

39 Bainbridge KE, Ramachandran V. Hearing aid use among older U.S. adults; the National health and nutrition examination survey, 20052006 and 2009-2010. Ear Hear 2014;35:289-94.

40 Dupraz J, Andersen-Ranberg K, Fors S, et al. Use of healthcare services and assistive devices among centenarians: results of the cross-sectional, international5-COOP study. BMJ Open 2020;10:e034296.

41 Giesbrecht EM, Smith EM, Mortenson WB, et al. Needs for mobility devices, home modifications and personal assistance among Canadians with disabilities. Health Rep 2017;28:9-15.

42 Smith EM, Giesbrecht EM, Mortenson WB, et al. Prevalence of wheelchair and scooter use among community-dwelling Canadians. Phys Ther 2016:96:1135-42.

43 Gale CR, Cooper C, Sayer AA. Prevalence of frailty and disability: findings from the English longitudinal study of ageing. Age Ageing 2015;44:162-5.

44 Gell NM, Wallace RB, LaCroix AZ, et al. Mobility device use in older adults and incidence of falls and worry about falling: findings from the 2011-2012 National health and aging trends study. J Am Geriatr Soc 2015;63:853-9.

45 Iwashyna TJ, Christie JD. Low use of durable medical equipment by chronically disabled elderly. J Pain Symptom Manage 2007:33:324-30.

46 Wolff JL, Agree EM, Kasper JD. Wheelchairs, walkers, and canes: what does Medicare pay for, and who benefits? Health Aff 2005;24:1140-9.

47 Tataryn M, Polack S, Chokotho L, et al. Childhood disability in Malawi: a population based assessment using the key informant method. BMC Pediatr 2017:17:198.

48 Theis KA, Steinweg A, Helmick CG, et al. Which one? What kind? How many? Types, causes, and prevalence of disability among U.S. adults. Disabil Health J 2019;12:411-21.

49 Cornman JC, Freedman VA. Racial and ethnic disparities in mobility device use in late life. J Gerontol B Psychol Sci Soc Sci 2008;63:S34-41.

50 Azizoğlu S, Crewther SG, Şerefhan F, et al. Evidence for the need for vision screening of school children in turkey. BMC Ophthalmol 2017;17:230.

51 Marmamula S, Keeffe JE, Narsaiah S, et al. Changing trends in the prevalence of visual impairment, uncorrected refractive errors and use of spectacles in Mahbubnagar district in South India. Indian $J$ Ophthalmol 2013;61:755-8.

52 Muhit M, Minto H, Parvin A, et al. Prevalence of refractive error, presbyopia, and unmet need of spectacle coverage in a northern district of Bangladesh: rapid assessment of refractive error study. Ophthalmic Epidemiol 2018;25:126-32.

53 Chan VF, Mebrahtu G, Ramson P, et al. Prevalence of refractive error and spectacle coverage in Zoba Ma'ekel Eritrea: a rapid assessment of refractive error. Ophthalmic Epidemiol 2013;20:131-7.

54 Loughman J, Nxele LL, Faria C, et al. Rapid assessment of refractive error, presbyopia, and visual impairment and associated quality of life in Nampula, Mozambique. $J$ Vis Impair Blind 2015;109:199-212.

55 Marmamula S, Keeffe JE, Rao GN. Uncorrected refractive errors, presbyopia and spectacle coverage: results from a rapid assessment of refractive error survey. Ophthalmic Epidemiol 2009;16:269-74.

56 Taylor HR, Xie J, Fox S, et al. The prevalence and causes of vision loss in Indigenous Australians: the National Indigenous eye health survey. Med J Aust 2010;192:312-8.
57 Ramke J, Brian G, Naduvilath T. Refractive error and presbyopia in timor-leste: the impact of 5 years of a national spectacle program. Invest Ophthalmol Vis Sci 2012;53:434-9.

58 Fricke TR, Tahhan N, Resnikoff S, et al. Global prevalence of presbyopia and vision impairment from uncorrected presbyopia: systematic review, meta-analysis, and modelling. Ophthalmology 2018;125:1492-9.

59 Casas Luque L, Naidoo K, Chan VF, et al. Prevalence of refractive error, presbyopia, and spectacle coverage in Bogotá, Colombia: a rapid assessment of refractive error. Optom Vis $\mathrm{Sci}$ 2019;96:579-86.

60 Robinson B, Feng Y, Woods CA, et al. Prevalence of visual impairment and uncorrected refractive error - report from a Canadian urban population-based study. Ophthalmic Epidemiol 2013;20:123-30.

61 Umar MM, Muhammad N, Alhassan MB. Prevalence of presbyopia and spectacle correction coverage in a rural population of North West Nigeria. Clin Ophthalmol 2015;9:1195-201.

62 Abdullah AS, Jadoon MZ, Akram M, et al. Prevalence of uncorrected refractive errors in adults aged 30 years and above in a rural population in Pakistan. $J$ Ayub Med Coll Abbottabad 2015;27:8-12.

63 Laitinen A, Koskinen S, Härkänen T, et al. A nationwide populationbased survey on visual acuity, near vision, and self-reported visual function in the adult population in Finland. Ophthalmology 2005;112:2227-37.

$64 \mathrm{He} \mathrm{M}$, Abdou A, Naidoo KS, et al. Prevalence and correction of near vision impairment at seven sites in China, India, Nepal, niger, South Africa, and the United States. Am J Ophthalmol 2012;154:107-16.

$65 \mathrm{He} \mathrm{M}$, Abdou A, Ellwein LB, et al. Age-Related prevalence and Met need for correctable and uncorrectable near vision impairment in a multi-country study. Ophthalmology 2014;121:417-22.

66 Hookway LA, Frazier M, Rivera N, et al. Population-Based study of presbyopia in Nicaragua. Clin Exp Optom 2016;99:559-63.

67 Naidoo KS, Jaggernath J, Martin C, et al. Prevalence of presbyopia and spectacle coverage in an African population in Durban, South Africa. Optom Vis Sci 2013;90:1424-9.

68 Ntodie M, Abu SL, Kyei S, et al. Near vision spectacle coverage and barriers to near vision correction among adults in the Cape coast Metropolis of Ghana. Afr Health Sci 2017:17:549-55.

69 Sapkota YD, Dulal S, Pokharel GP, et al. Prevalence and correction of near vision impairment at Kaski, Nepal. Nepal J Ophthalmol 2012;4:17-22.

70 Uche N, Ezegwui I, Uche E, et al. Prevalence of presbyopia in a rural African community. Rural Remote Health 2014;14:2731.

71 Cheng F, Shan L, Song W, et al. Distance- and near-visual impairment in rural Chinese adults in Kailu, inner Mongolia. Acta Ophthalmol 2016:94:407-13.

72 Gupta N, Vashist P, Malhotra S, et al. Rapid assessment of visual impairment in urban population of Delhi, India. PLOS One 2015;10:e0124206.

73 Laviers HR, Omar F, Jecha H, et al. Presbyopic spectacle coverage, willingness to pay for near correction, and the impact of correcting uncorrected presbyopia in adults in Zanzibar, East Africa. Invest Ophthalmol Vis Sci 2010;51:1234-41.

$74 \mathrm{Lu}$ Q, He W, Murthy GVS, et al. Presbyopia and near-vision impairment in rural Northern China. Invest Ophthalmol Vis Sci 2011:52:2300-5.

75 Mansberger SL, Romero FC, Smith NH, et al. Causes of visual impairment and common eye problems in northwest American Indians and Alaska natives. Am J Public Health 2005;95:881-6.

76 Marmamula S, Madala SR, Rao GN. Prevalence of uncorrected refractive errors, presbyopia and spectacle coverage in marine fishing communities in South India: rapid assessment of visual impairment (RAVI) project. Ophthalmic Physiol Opt 2012;32:149-55

77 Marmamula S, Narsaiah S, Shekhar K, et al. Presbyopia, spectacles use and spectacle correction coverage for near vision among cloth weaving communities in Prakasam district in South India. Ophthalmic Physiol Opt 2013;33:597-603.

78 Marmamula S, Khanna RC, Narsaiah S, et al. Prevalence of spectacles use in Andhra Pradesh, India: rapid assessment of visual impairment project. Clin Exp Ophthalmol 2014;42:227-34

79 Marmamula S, Khanna RC, Kunuku E, et al. Near visual impairment and spectacle coverage in Telangana, India. Clin Exp Ophthalmol 2017:45:568-74.

80 Ramke J, du Toit R, Palagyi A, et al. Correction of refractive error and presbyopia in Timor-Leste. Br J Ophthalmol 2007;91:860-6.

81 Cunha CC, Berezovsky A, Furtado JM, et al. Presbyopia and ocular conditions causing near vision impairment in older adults from the Brazilian Amazon region. Am J Ophthalmol 2018;196:72-81. 
82 Sherwin JC, Keeffe JE, Kuper H, et al. Functional presbyopia in a rural Kenyan population: the unmet presbyopic need. Clin Exp Ophthalmol 2008;36:245-51.

83 Zebardast N, Friedman DS, Vitale S. The prevalence and demographic associations of presenting Near-Vision impairment among adults living in the United States. Am J Ophthalmol 2017; 174:134-44.

84 Otte B, Woodward MA, Ehrlich JR, et al. Self-Reported eyeglass use by US Medicare beneficiaries aged 65 years or older. JAMA Ophthalmol 2018;136:1047-50.

85 Kodjebacheva G, Brown ER, Estrada L, et al. Uncorrected refractive error among first-grade students of different racial/ ethnic groups in southern California: results a year after schoolmandated vision screening. J Public Health Manag Pract 2011:17:499-505

86 Naidoo KS, Chinanayi FS, Ramson P, et al. Rapid assessment of refractive error in the eThekwini Municipality of KwaZulu-Natal, Durban, South Africa. Clin Exp Optom 2016;99:360-5.

87 Goujon N, Brown CM, Xie J, et al. Self-Reported vision and health of Indigenous Australians. Clin Exp Ophthalmol 2010;38:796-804.

88 Vitale S, Cotch MF, Sperduto R, et al. Costs of refractive correction of distance vision impairment in the United States, 1999-2002. Ophthalmology 2006;113:2163-70.

89 Malhotra S, Kalaivani M, Rath R, et al. Use of spectacles for distance vision: coverage, unmet needs and barriers in a rural area of North India. BMC Ophthalmol 2019;19:252.

90 Foreman J, Xie J, Keel S, et al. Treatment coverage rates for refractive error in the National eye health survey. PLoS One 2017;12:e0175353.

91 Shah SP, Jadoon MZ, Dineen B, et al. Refractive errors in the adult Pakistani population: the National blindness and visual impairment survey. Ophthalmic Epidemiol 2008;15:183-90.

92 Ramsewak SSA, Verlander N, Deomansingh F. National eye survey of Trinidad and Tobago: the prevalence and risk factors for refractive error. Investigative Ophthalmology and Visual Science 2016;57:3976.

93 Foreman J, Xie J, Keel S, et al. The prevalence and causes of vision loss in Indigenous and non-Indigenous Australians: the National eye health survey. Ophthalmology 2017;124:1743-52

94 Gilbert C, Murthy GVS, Schmidt E, et al. Prevalence and types of refractive errors, and spectacle coverage in Sri Lankan adults: the Sri Lanka national survey of blindness and visual impairment. Ceylon Med J 2018;63:33.

95 Marmamula S, Khanna RC, Kunkunu E, et al. Population-Based assessment of prevalence and causes of visual impairment in the state of Telangana, India: a cross-sectional study using the rapid assessment of visual impairment (RAVI) methodology. BMJ Open 2016;6:e012617

96 Flaxman SR, Bourne RRA, Resnikoff S, et al. Global causes of blindness and distance vision impairment 1990-2020: a systematic review and meta-analysis. Lancet Glob Health 2017;5:e1221-34.

97 Malhotra S, Vashist P, Gupta N, et al. Prevalence and causes of visual impairment among adults aged 15-49 years in a rural area of north India - A population-based study. Indian J Ophthalmol 2018;66:951-6.

98 Murthy GVS, Vashist P, John N, et al. Prevelence and causes of visual impairment and blindness in older adults in an area of India with a high cataract surgical rate. Ophthalmic Epidemiol 2010;17:185-95.

99 Zhao J, Ellwein LB, Cui H, et al. Prevalence of vision impairment in older adults in rural China: the China Nine-Province survey. Ophthalmology 2010;117:409-16.

100 Naël V, Moreau G, Monfermé S, et al. Prevalence and associated factors of uncorrected refractive error in older adults in a population-based study in France. JAMA Ophthalmol 2019;137:3-11.

101 Friedman DS, Repka MX, Katz J, et al. Prevalence of decreased visual acuity among preschool-aged children in an American urban population: the Baltimore pediatric eye disease study, methods, and results. Ophthalmology 2008;115:1786.

102 Giordano L, Friedman DS, Repka MX, et al. Prevalence of refractive error among preschool children in an urban population: the Baltimore pediatric eye disease study. Ophthalmology 2009;116:739.

103 Pai AS-I, Wang JJ, Samarawickrama C, et al. Prevalence and risk factors for visual impairment in preschool children the Sydney paediatric eye disease study. Ophthalmology 2011;118:1495-500.

104 Hendler K, Mehravaran S, Lu X, et al. Refractive errors and amblyopia in the UCLA preschool vision program; first year results. Am J Ophthalmol 2016;172:80-6.
105 Margines JB, Huang C, Young A, et al. Refractive errors and amblyopia among children screened by the UCLA preschool vision program in Los Angeles County. Am J Ophthalmol 2020;210:78-85.

106 Mehravaran S, Duarte PB, Brown SI, et al. The UCLA preschool vision program, 2012-2013. J Aapos 2016;20:63-7.

107 Zhang X, Wang Y, Huang D, et al. Prevalence of reduced visual acuity among preschool children in eastern China and comparison at a 5-year interval. Clin Exp Ophthalmol 2018;46:994-1001.

108 Ma Y, Qu X, Zhu X, et al. Age-Specific prevalence of visual impairment and refractive error in children aged 3-10 years in Shanghai, China. Invest Ophthalmol Vis Sci 2016;57:6188-96.

109 Robaei D, Rose K, Ojaimi E, et al. Visual acuity and the causes of visual loss in a population-based sample of 6-year-old Australian children. Ophthalmology 2005;112:1275-82.

$110 \mathrm{He} \mathrm{J,} \mathrm{Lu} \mathrm{L,} \mathrm{Zou} \mathrm{H,} \mathrm{et} \mathrm{al.} \mathrm{Prevalence} \mathrm{and} \mathrm{causes} \mathrm{of} \mathrm{visual}$ impairment and rate of wearing spectacles in schools for children of migrant workers in Shanghai, China. BMC Public Health 2014;14:1312.

111 Hashemi H, Yekta A, Saatchi M, et al. The Met and unmet need for refractive correction and its determinants in 7-year-old children. British Journal of Visual Impairment 2017;35:69-80.

112 Gursoy H, Basmak H, Yaz Y, et al. Vision screening in children entering school: Eskisehir, Turkey. Ophthalmic Epidemiol 2013;20:232-8.

113 Casson RJ, Kahawita S, Kong A, et al. Exceptionally low prevalence of refractive error and visual impairment in schoolchildren from Lao people's Democratic Republic. Ophthalmology 2012;119:2021-7.

114 Hashim SE, Tan HK, Wan-Hazabbah WH. Prevalence of refractive error in Malay primary school children in suburban area of Kota Bharu, Kelantan, Malaysia. Annals of the Academy of Medicine Singapore 2008;37:940-6.

115 Aldebasi YH. Prevalence of correctable visual impairment in primary school children in Qassim Province, Saudi Arabia. J Optom 2014;7:168-76.

116 Choy BNK, You Q, Zhu MM, et al. Prevalence and associations of myopia in Hong Kong primary school students. Jpn J Ophthalmol 2020;64:437-49.

117 Harrington SC, Stack J, Saunders K, et al. Refractive error and visual impairment in Ireland schoolchildren. $\mathrm{Br} J$ Ophthalmol 2019:103:1112-8.

118 O'Donoghue L, McClelland JF, Logan NS, et al. Refractive error and visual impairment in school children in Northern Ireland. $\mathrm{Br} J$ Ophthalmol 2010;94:1155-9.

119 Al Wadaani FA, Amin TT, Ali A. Prevalence and pattern of refractive errors among primary school children in al Hassa, Saudi Arabia. Glob J Health Sci 2013;5:125-34.

120 Gupta A, Lal R, Mazta SR. Prevalence of refractive errors, color vision defects and other ocular disorders in school-going children: primary screening by school teachers. Journal International Medical Sciences Academy 2012;25:223-4.

121 Hameed A. Screening for refractive errors and visual impairment among school children in Kohat, Pakistan. Rawal Medical Journal 2016;41:437-40.

122 He M, Zeng J, Liu Y, et al. Refractive error and visual impairment in urban children in southern China. Invest Ophthalmol Vis Sci 2004:45:793-9.

$123 \mathrm{He} \mathrm{M}, \mathrm{Xu}$ J, Yin Q, et al. Need and challenges of refractive correction in urban Chinese school children. Optom Vis Sci 2005;82:26-44.

124 Kassa T, Alene GD. Prevalence of refractive errors in pre-school and school children of Debark and kola Diba towns, northwestern Ethiopia. Ethiopian Journal of Health Development 2004;17:117-24.

$125 \mathrm{Hu}$ M, Zhou Y, Huang S, et al. Population prevalence of myopia, glasses wear and free glasses acceptance among minority versus Han schoolchildren in China. PLoS One 2019;14:e0215660.

126 Kaur G, Koshy J, Thomas S, et al. Vision screening of school children by teachers as a community based strategy to address the challenges of childhood blindness. J Clin Diagn Res 2016;10:NC09-14

127 Dandona R, Dandona L, Srinivas M, et al. Refractive error in children in a rural population in India. Invest Ophthalmol Vis Sci 2002;43:615-22.

128 Falkenberg HK, Langaas T, Svarverud E. Vision status of children aged 7-15years referred from school vision screening in Norway during 2003-2013: a retrospective study. BMC Ophthalmol 2019:19:N.PAG-N.PAG.

129 Goh P-P, Abqariyah Y, Pokharel GP, et al. Refractive error and visual impairment in school-age children in Gombak district, Malaysia. Ophthalmology 2005;112:678-85. 
130 Kedir J, Girma A. Prevalence of refractive error and visual impairment among rural school-age children of Goro district, Gurage zone, Ethiopia. Ethiop J Health Sci 2014;24:353-8.

131 Pavithra MB, Hamsa L, Madhukumar S. Factors associated with spectacle-wear compliance among school children of 7-15 years in South India. Int J Med Public Health 2014:4:146.

132 Wang X, Yi H, Lu L, et al. Population prevalence of need for spectacles and spectacle ownership among urban migrant children in eastern China. JAMA Ophthalmol 2015;133:1399-406.

133 Yekta A, Fotouhi A, Hashemi H, et al. Prevalence of refractive errors among schoolchildren in Shiraz, Iran. Clin Exp Ophthalmol 2010;38:242-8.

134 Zhu Z, Ellwein LB, Wang SK, et al. Meeting the need for corrective spectacles in visually impaired Chinese school children: the potential of ready-made spectacles. $\mathrm{Br} \mathrm{J} \mathrm{Ophthalmol}$ 2019;103:1106-11.

$135 \mathrm{Li}$ Z, Xu K, Wu S, et al. Population-Based survey of refractive error among school-aged children in rural Northern China: the Heilongjiang eye study. Clin Exp Ophthalmol 2014;42:379-84.

136 Barria F, Conte F, Muñoz S, et al. Prevalence of refractive error and spectacle coverage in schoolchildren in two urban areas of Chile. Rev Panam Salud Publica 2018;42:1-8.

137 Robaei D, Huynh SC, Kifley A, et al. Correctable and noncorrectable visual impairment in a population-based sample of 12-year-old Australian children. Am J Ophthalmol 2006;142:112.

138 Robaei D, Kifley A, Rose KA, et al. Refractive error and patterns of spectacle use in 12-year-old Australian children. Ophthalmology 2006;113:1567-73.

139 Yamamah GAN, Talaat Abdel Alim AA, Mostafa YSED, et al. Prevalence of visual impairment and refractive errors in children of South Sinai, Egypt. Ophthalmic Epidemiol 2015;22:246-52.

140 Mehari ZA, Yimer AW. Prevalence of refractive errors among schoolchildren in rural central Ethiopia. Clin Exp Optom 2013;96:65-9.

141 Plainis S, Moschandreas J, Nikolitsa P, et al. Myopia and visual acuity impairment: a comparative study of Greek and Bulgarian school children. Ophthalmic Physiol Opt 2009;29:312-20.

142 Sapkota YD, Adhikari BN, Pokharel GP, et al. The prevalence of visual impairment in school children of upper-middle socioeconomic status in Kathmandu. Ophthalmic Epidemiol 2008;15:17-23.

143 Salomão SR, Cinoto RW, Berezovsky A, et al. Prevalence and causes of visual impairment in low-middle income school children in Sao Paulo, Brazil. Invest Ophthalmol Vis Sci 2008;49:4308-13.

144 AEED A, Ewis AAE, Mahran WM. Prevalence and risk factors of refractive errors among preparatory school students in Beni-Suef, Egypt. Journal of Public Health 2019;27:43-7.

145 Gao Z, Meng N, Muecke J, et al. Refractive error in school children in an urban and rural setting in Cambodia. Ophthalmic Epidemiol 2012;19:16-22.

146 Qian D-J, Zhong H, Li J, et al. Spectacles utilization and its impact on health-related quality of life among rural Chinese adolescents. Eye 2018;32:1879-85

147 Ajaiyeoba Al, Isawumi MA, Adeoye AO, et al. Pattern of eye diseases and visual impairment among students in southwestern Nigeria. Int Ophthalmol 2007;27:287-92.

148 Congdon N, Wang Y, Song Y, et al. Visual disability, visual function, and myopia among rural chinese secondary school children: the Xichang Pediatric Refractive Error Study (X-PRES)--report 1. Invest Ophthalmol Vis Sci 2008;49:2888-94.

149 Congdon N, Zheng M, Sharma A, et al. Prevalence and determinants of spectacle nonwear among rural Chinese secondary schoolchildren: the Xichang pediatric refractive error study report 3. Arch Ophthalmol 2008;126:1717-23.

150 Li L, Song Y, Liu X, et al. Spectacle acceptance among secondary school students in rural China: the Xichang Pediatric Refractive Error Study (X-PRES)--report 5. Invest Ophthalmol Vis Sci 2008;49:2895-902.

151 Zhang M, Lv H, Gao Y, et al. Visual morbidity due to inaccurate spectacles among school children in rural China: the see well to learn well project, report 1. Invest Ophthalmol Vis Sci 2009;50:2011-7.

152 He M, Huang W, Zheng Y, et al. Refractive error and visual impairment in school children in rural southern China. Ophthalmology 2007;114:793-9.

153 Abu EK, Yeboah AA, Ocansey S, et al. Epidemiology of ocular disorders and visual impairment among school pupils in the Cape coast Metropolis, Ghana. Br J Vis Impair 2015;33:45-53.

154 Alsaqr A, Abu Sharha A, Fagehi R, et al. The visual status of adolescents in Riyadh, Saudi Arabia: a population study. Clin Ophthalmol 2018;12:965-72.
155 Zhao J, Guan H, Du K, et al. Visual impairment and spectacles ownership among upper secondary school students in northwestern China. Hong Kong Med J 2020;26:35-43.

156 Wu LJ, You QS, Duan JL, et al. Prevalence and associated factors of myopia in high-school students in Beijing. PLoS One 2015;10:e0120764

157 Wedner SH, Ross DA, Todd J, et al. Myopia in secondary schoo students in Mwanza City, Tanzania: the need for a national screening programme. Br J Ophthalmol 2002;86:1200-6.

158 Senicato C, Barros MBdeA. Social inequality in health among women in Campinas, São Paulo state, Brazil. Cadernos de Saúde Pública 2012;28:1903-14.

159 Ferraz FH, Corrente JE, Opromolla P, et al. Influence of uncorrected refractive error and unmet refractive error on visual impairment in a Brazilian population. BMC Ophthalmol 2014:14:84

160 Hashemi H, Rezvan F, Yekta A, et al. The prevalence and causes of Visaual impairment and blindness in a rural population in the North of Iran. Iran J Public Health 2015;44:855-64.

161 Hashemi H, Abbastabar H, Yekta A, et al. The prevalence of uncorrected refractive errors in underserved rural areas. J Curr Ophthalmol 2017;29:305-9.

162 Fotouhi A, Hashemi H, Raissi B, et al. Uncorrected refractive errors and spectacle utilisation rate in Tehran: the unmet need. $\mathrm{Br} \mathrm{J}$ Ophthalmol 2006;90:534-7.

163 Danermark B, Hanning M. Hearing and vision: health in Sweden: the National public health report 2012. Chapter 17. Scand J Public Health 2012;40:287-92.

164 Desalegn A, Tsegaw A, Shiferaw D, et al. Knowledge, attitude, practice and associated factors towards spectacles use among adults in Gondar town, Northwest Ethiopia. BMC Ophthalmol 2016;16:184.

165 Hashemi H, Khabazkhoob M, Emamian MH, et al. Visual impairment in the 40- to 64-year-old population of Shahroud, Iran Eye 2012;26:1071-7.

166 Ertekin YH, Tekin M, Uludag A, et al. Vision screening in children: is 7-9 years of age a threshold for visual impairment? Pak J Med Sci 2016;32:1194-8.

167 Latorre-Arteaga S, Fernández-Sáez J, Gil-González D. Inequities in visual health and health services use in a rural region in Spain. Gac Sanit 2018;32:439-46.

168 Sheeladevi S, Seelam B, Nukella PB, et al. Prevalence of refractive errors, uncorrected refractive error, and presbyopia in adults in India: a systematic review. Indian J Ophthalmol 2019;67:583-92.

169 Tahhan N, Fricke TR, Naduvilath T, et al. Uncorrected refractive error in the Northern and eastern provinces of Sri Lanka. Clin Exp Optom 2009;92:119-25.

170 Resnikoff S, Pascolini D, Mariotti SP, et al. Global magnitude of visual impairment caused by uncorrected refractive errors in 2004. Bull World Health Organ 2008;86:63-70.

171 Rosman M, Wong TY, Tay W-T, et al. Prevalence and risk factors of undercorrected refractive errors among Singaporean Malay adults: the Singapore Malay eye study. Invest Ophthalmol Vis Sci 2009;50:3621-8.

172 Huang OS, Zheng Y, Tay WT, et al. Lack of awareness of common eye conditions in the community. Ophthalmic Epidemiol 2013;20:52-60.

173 Vitale S, Cotch MF, Sperduto RD. Prevalence of visual impairment in the United States. JAMA 2006;295:2158-63.

174 Mashayo ER, Chan VF, Ramson P, et al. Prevalence of refractive error, presbyopia and spectacle coverage in Kahama district, Tanzania: a rapid assessment of refractive error. Clin Exp Optom 2015:98:58-64.

175 Aljied R, Aubin M-J, Buhrmann R, et al. Prevalence and determinants of visual impairment in Canada: cross-sectional data from the Canadian longitudinal study on aging. Can J Ophthalmol 2018;53:291-7.

176 Nangia V, Jonas JB, Gupta R, et al. Visual impairment and blindness in rural central India: the central India eye and medical study. Acta Ophthalmol 2013;91:483-6.

177 Bourne RRA, Dineen BP, Huq DMN, et al. Correction of refractive error in the adult population of Bangladesh: meeting the unmet need. Invest Ophthalmol Vis Sci 2004;45:410-7.

178 Laitinen A, Koskinen S, Rudanko S-L, et al. Use of eye care services and need for assistance in the visually impaired. Optom Vis Sci 2008;85:341-9.

179 Han X, Liao C, Liu C, et al. Incidence and correction of vision impairment among elderly population in southern urban China. Clin Exp Ophthalmol 2019;47:439-44.

180 Budenz DL, Bandi JR, Barton K, et al. Blindness and visual impairment in an urban West African population: the Tema eye survey. Ophthalmology 2012;119:1744-53. 
181 Casson RJ, Newland HS, Muecke J, et al. Prevalence and causes of visual impairment in rural Myanmar: the Meiktila eye study. Ophthalmology 2007;114:2302-8.

182 Ezelum C, Razavi H, Sivasubramaniam S, et al. Refractive error in Nigerian adults: prevalence, type, and spectacle coverage. Invest Ophthalmol Vis Sci 2011;52:5449-56.

183 Marmamula S, Shekhar K, Banerjee S, et al. Population-Based assessment of unilateral visual impairment in the South Indian state of Andhra Pradesh: rapid assessment of visual impairment (RAVI) project. Ophthalmic Epidemiol 2016;23:171-5.

184 Marmamula S, Khanna RC, Kunuku E, et al. Spectacles use in a rural population in the state of Telangana in South India. Indian $J$ Ophthalmol 2017;65:509-15.

185 Marmamula S, Challa R, Yellapragada S, et al. Temporal trends in the prevalence of spectacle use and spectacle coverage in India. Clin Exp Optom 2020;103:693-8.

186 Marmamula S, Yellapragada S, Khanna RC. Population Based Assessment of Prevalence and Causes of Vision Impairment in the North-eastern State of Tripura, India - The Tripura Eye Survey. Ophthalmic Epidemiol 2020;27:283-8.

187 Prema R, George R, Sathyamangalam Ve R, et al. Comparison of refractive errors and factors associated with spectacle use in a rural and urban South Indian population. Indian J Ophthalmol 2008;56:139-44.

188 Tafida A, Kyari F, Abdull MM, et al. Poverty and blindness in Nigeria: results from the National survey of blindness and visual impairment. Ophthalmic Epidemiol 2015;22:333-41.

189 Zheng Y, Lavanya R, Wu R, et al. Prevalence and causes of visual impairment and blindness in an urban Indian population: the Singapore Indian eye study. Ophthalmology 2011;118:1798-804.

190 Pan C-W, Qian D-J, Sun H-P, et al. Visual impairment among older adults in a rural community in eastern China. J Ophthalmol 2016;2016:1-6.

191 Furtado JM, Berezovsky A, Ferraz NN, et al. Prevalence and causes of visual impairment and blindness in adults aged 45 years and older from Parintins: the Brazilian Amazon region eye survey. Ophthalmic Epidemiol 2019;26:345-54.

192 Bastawrous A, Mathenge W, Foster A, et al. Prevalence and predictors of refractive error and spectacle coverage in Nakuru, Kenya: a cross-sectional, population-based study. Int Ophthalmol 2013;33:541-8

193 Gallarreta M, Furtado JM, Lansingh VC, et al. Rapid assessment of avoidable blindness in Uruguay: results of a nationwide survey. Rev Panam Salud Publica 2014;36:219-24.

194 Lee L, D'Esposito F, Garap J, et al. Rapid assessment of avoidable blindness in Papua New Guinea: a nationwide survey. $\mathrm{Br} J$ Ophthalmol 2019;103:338-42.

195 Marmamula S, Ravuri CSLV, Boon MY, et al. A cross-sectional study of visual impairment in elderly population in residential care in the South Indian state of Andhra Pradesh: a cross-sectional study. BMJ Open 2013;3:e002576.

196 Neena J, Rachel J, Praveen V, et al. Rapid assessment of avoidable blindness in India. PLoS One 2008;3:e2867.

197 Nirmalan PK, Thulasiraj RD, Maneksha V, et al. A population based eye survey of older adults in Tirunelveli district of South India: blindness, cataract surgery, and visual outcomes. $\mathrm{Br} J$ Ophthalmol 2002;86:505-12

198 Patil S, Gogate P, Vora S, et al. Prevalence, causes of blindness, visual impairment and cataract surgical services in Sindhudurg district on the Western coastal strip of India. Indian J Ophthalmol 2014:62:240-5.

199 Vignesh D, Gupta N, Kalaivani M, et al. Prevalence of visual impairment and its association with vision-related quality of life among elderly persons in a resettlement colony of Delhi. J Family Med Prim Care 2019;8:1432.

200 Zhu M, Tong X, Zhao R, et al. Visual impairment and spectacle coverage rate in Baoshan district, China: population-based study. BMC Public Health 2013;13:311.

201 Choi S, Stagg BC, Ehrlich JR. Disparities in Low-Vision device use among older us Medicare recipients. JAMA Ophthalmol 2018;136:1399-403.

202 Kuang T-M, Tsai S-Y, Hsu W-M, et al. Correctable visual impairment in an elderly Chinese population in Taiwan: the Shihpai eye study. Invest Ophthalmol Vis Sci 2007;48:1032-7.

203 Lindsay S, Tsybina I. Predictors of unmet needs for communication and mobility assistive devices among youth with a disability: the role of socio-cultural factors. Disabil Rehabil Assist Technol $2011 ; 6: 10-21$.
204 Eide AH, van Rooy G, Loeb ME. Living conditions among people with activity limitations in Namibia: a representative, national study. Trondheim, Norway, 2003.

205 Eide AH, Nhiwathiwa S, Muderedzi J. Living conditions among people with activity limitations in Zimbabwe. A representative regional survey, 2003.

206 Eide A, Loeb M. Living conditions among people with activity limitations in Zambia. A national representative study. SINTEF, 2006.

207 Eide AH, Neupane S, Hem K-G. Living conditions among people with disability in Nepal, 2016.

208 Eide AH, Munthali A. Living conditions among persons with disabilities in Malawi, a national, representative survey 2017, 2018.

209 JB EAH. Living conditions among people with disabilities in Swaziland a national representative study. Trondheim, Norway, 2011.

210 Eide AH, Kamaleri Y, Hem K-G. Living conditions among people with disabilities in Mozambique: a national representative study, 2009.

211 Eide AH, Mmatli T. Living conditions among people with disability in Botswana. Trondheim, Norway: SINTEF, 2016.

212 Kamaleri Y, Eide AH. Living conditions among people with disabilities in Lesotho. Trondheim, Norway, 2011.

213 Loeb M, Eide AH. Living conditions among people with activity limitations in Malawi: a national representative study. Trondheim, Norway, 2004.

214 Maart S, Jelsma J. Disability and access to health care - a community based descriptive study. Disabil Rehabil 2014:36:1489-93

215 Smith N. The face of disability in Nigeria: a disability survey in Kogi and niger states. DCID 2011;22:35-47.

216 Eide A, Sinyenga G, Phiri Mwansa O. 2015 Zambia national disability survey, 2018.

217 Visagie S, Eide AH, Mannan $\mathrm{H}$, et al. A description of assistive technology sources, services and outcomes of use in a number of African settings. Disabil Rehabil Assist Technol 2017:12:705-12.

218 Loggins S, Alston R, Lewis A. Utilization of assistive technology by persons with physical disabilities: an examination of predictive factors by race. Disabil Rehabil Assist Technol 2014;9:487-92.

219 Marella M, Devine A, Armecin GF, et al. Rapid assessment of disability in the Philippines: understanding prevalence, well-being, and access to the community for people with disabilities to inform the W-DARE project. Popul Health Metr 2016;14:1-11.

220 Matter RA, Eide AH. Access to assistive technology in two southern African countries. BMC Health Serv Res 2018;18:792.

221 Goins RT, Spencer SM, Goli S, et al. Assistive technology use of older American Indians in a southeastern tribe: the native elder care study. J Am Geriatr Soc 2010;58:2185-90.

222 Frochen S, Mehdizadeh S. Functional status and adaptation: measuring activities of daily living and device use in the National health and aging trends study. J Aging Health 2018;30:1136-55.

223 Rios A, Miguel Cruz A, Guarín MR, et al. What factors are associated with the provision of assistive technologies: the Bogotá D.C. case. Disabil Rehabil 2014:9:432-44.

224 Burton MJ, Ramke J, Marques AP, et al. The Lancet global health Commission on global eye health: vision beyond 2020. Lancet Glob Health 2021;9:e489-551.

225 World Health Organisation. Prevalence of coverage of assistive technology in the who European region: a scoping review, 2021 Available: http://apps. who.int/bookorders [Accessed 5 Nov 2021]

226 Holloway C, Austin V, Barbareschi G. Scoping research report on assistive technology: on the road for universial assistive technology coverage, 2018. Available: https://at2030.org/static/at2030 core/ outputs/-Scoping-Report_2019-compressed-192.pdf [Accessed 15 Nov 2021].

227 Rohwerder B. Assistive technologies in developing countries 2018.

228 Mishra S, Pupulin A, Ekman B, et al. National priority assistive product list development in low resource countries: lessons learned from Tajikistan. Disabil Rehabil Assist Technol. In Press 2021;16:857-64.

229 Danemayer J, Bhot W, Kular A. At data portal. Available: https:// at2030.org/at-data-portal/map/ [Accessed 23 Nov 2021].

230 Danemayer J, Boggs D, Ramos D V. Estimating need and coverage for five priority assistive products. AT2030 programme, 2021. Available: https://at2030.org/estimating-need-andcoverage-for-five-priority-assistive-products/ [Accessed $23 \mathrm{Nov}$ 2021]. 